\title{
COVID-19: a Disease with a Potpourri of Histopathologic Findings-a Literature Review and Comparison to the Closely Related SARS and MERS
}

\author{
Preeti Malik $^{1}$ D $\cdot$ Karan Patel $^{2} \cdot$ Muhammed Akrmah $^{3} \cdot$ Deepak Donthi $^{4} \cdot$ Urvish Patel $^{1} \cdot$ Samer N. Khader $^{5}$. \\ Saeed Asiry ${ }^{6}$
}

Accepted: 16 July 2021 / Published online: 10 August 2021

(C) The Author(s), under exclusive licence to Springer Nature Switzerland AG 2021

\begin{abstract}
Since the coronavirus disease 2019 (COVID-19) pandemic has hit the entire world, there is ample knowledge regarding its clinical course and prognostic biomarkers. Still, the pathophysiology of COVID-19 is poorly understood. Since the first guidelines published in February 2020 for autopsy of both confirmed and suspected COVID-19 cases, there has been an increasing number of autopsies and literature reporting histopathological findings. However, our knowledge about the immunological response of various organ systems to the virus, as well as response patterns, is inadequate but is essential to understand and initiate timely and targeted antiviral, anti-inflammatory, or anticoagulative therapy. Although severe acute respiratory syndrome coronavirus 2 (SARS-CoV-2) is primarily considered a respiratory virus, current evidence shows that it causes life-threatening complications in almost all organ systems including the heart, brain, kidney, spleen, liver, and eyes. Hence, in this article, we reviewed the published case reports and case series in order to increase our understanding of COVID-19 pathophysiology. The main histopathological findings of the lungs include diffuse alveolar damage with activated type II pneumocytes, fibroblasts, protein-rich exudate, and hyaline membranes. Other significant histopathological findings include cardiomegaly, right ventricular dilation, splenic pulp atrophy, kidneys with severe podocytopathy, and collapsing glomerulopathy, and the brain showed hypoxic changes in the cerebellum and cerebrum. Furthermore, in this review, we also explained different pathological findings of SARS-CoV and MERS and compared them to SARS-CoV-2. This comprehensive review will improve our understanding of COVID-19 pathophysiology and various disease stages, hence promoting the application of targeted therapy.
\end{abstract}

Keywords Coronavirus $\cdot$ COVID-19 $\cdot$ Pathology $\cdot$ SARS-CoV-2 $\cdot$ Diffuse alveolar damage

This article is part of the Topical Collection on Covid-19

Preeti Malik

pmalik.ma@gmail.com

Karan Patel

Patelk48@ rowan.edu

Muhammed Akrmah

muhammad.akrmah@hhchealth.org

Deepak Donthi

DONTHID17@ecu.edu

Urvish Patel

dr.urvish.patel@gmail.com

Samer N. Khader

samkhader@gmail.com
Saeed Asiry

sasiry@montefiore.org

1 Department of Pathology, Montefiore Medical Center, 111 East 210 street, Bronx, NY 10467, USA

2 Cooper Medical School of Rowan University, Camden, NJ, USA

3 Department of Pathology and Laboratory Medicine, Hartford Hospital, Hartford, CT, USA

4 Department of Pathology, Vidant Medical Center/East Carolina University, Greenville, SC, USA

5 Department of Pathology, University of Pittsburgh Medical Center, Pittsburgh, PA, USA

6 Department of Pathology, University of Colorado, Aurora, CO, USA 


\section{Background}

The coronavirus disease 2019 (COVID-19) pandemic has been a global threat since its beginning in Wuhan. It has now spread to over 200 countries and territories worldwide with global cases approaching 1.7 billion and 4 million deaths (as of June 4, 2021); it has become a serious public health crisis [1]. The USA has surpassed all countries in the number of COVID-19-positive cases and now stands at over 34 million cases with more than 611,630 deaths as of June 4, 2021 [2]. Other countries with high case rates and disease burden are India (28M), Brazil (16M), France (5.6M), Russia (5.1M), and the UK (4.5M) [1].

This pandemic has been a challenge for all healthcare professionals as patients are presenting with a variable clinical presentation from asymptomatic to mild symptoms including fever, dry cough, dyspnea, myalgia, sore throat, and headache, to more severe and emergent complications including acute respiratory distress syndrome (ARDS), pneumonia, and multiorgan failure requiring intensive care unit (ICU) admission and mechanical ventilation [3]. Recently, diarrhea, anosmia, and ageusia have also been reported in few studies along with neurologic manifestations [4]. There is an emerging literature on epidemiologic characteristics and diagnostic methods of COVID-19, but insights into disease pathogenesis are still evolving due to a limited number of autopsies.

It has been widely reported that severe acute respiratory syndrome coronavirus 2 (SARS-CoV-2) primarily affects the respiratory tract. While there has been a wide array of studies that have reported lung pathologies, the virus has also been known to pathologically affect other organs including the liver, gallbladder, kidney, spleen, heart, and brain. Many overlapping studies have reported a common array of gross and pathological findings in these organs. Some of the most commonly reported pathologic findings include diffuse alveolar damage (DAD), spleen atrophy, and glomerular damage. Given that the SARS-CoV-2 virus has only emerged recently, there has not yet been a consensus as to exactly what pathological changes in each organ system are the result of the virus. Developing a common consensus is made even more difficult by the fact that many patients often have multiple comorbidities further complicating the situation. In this article, we aim to conduct a most up-to-date literature review of the pathological and autopsy findings of COVID-19 patients. In understanding the histopathologic manifestations of the disease, we are hoping to provide a better insight into the pathogenesis of COVID-19.

\section{Systemic Pathological Manifestations of COVID-19}

\section{Lungs}

It has been well reported that SARS-CoV-2 primarily affects the respiratory system. As a result, many studies have found a wide array of pathologies in the lungs of patients who had contracted the virus. In one of the first studies by Edler et al. where they analyzed autopsies of 80 COVID-19 patients, they found significant pathological changes in the lungs of these patients including signs of ARDS on the lung surface and segmental hyperemia, protein-rich exudate, and purulent pneumonia. Histological findings included DAD with activated type II pneumocytes, fibroblasts, protein-rich exudate, and hyalinization of the membranes [5]. Another study by Tian et al. reported two patients with lung adenocarcinoma and had COVID-19 during hospitalization. Lung biopsies of these patients showed pulmonary edema, hyperplasia of pneumocytes, prominent proteinaceous exudates, vascular congestion, and inflammatory clusters with fibrinoid material and multinucleated giant cells away from the tumor due to COVID-19 (Figs. 1 and 2) [6]. A study of 10 COVID-19 autopsies by Fox et al. reported thrombosis and microangiopathy in small vessels and capillaries (Fig. 3) as well as diffuse alveolar damage, hyaline membrane formation, and parenchymal hemorrhage bilaterally (Fig. 4). Interestingly, they also found that the lungs of these patients were significantly (one standard deviation) heavier than the lungs of non-COVID-19 patients [7]. In the case of a 72-year-old male, Zhang et al. found denudation of alveolar cells, type II pneumocyte hyperplasia, intra-alveolar fibrinous exudates, interstitial loose fibrosis, and intra-alveolar fibrous plugs, all consistent with the findings of DAD [8]. In addition to the previously reported findings, Aguiar et al. found moderate amounts of intraalveolar macrophages and small amounts of polymorphonuclear neutrophils (PMN) and lymphocytes, alongside intraalveolar hemorrhages and bacterial proliferation in the alveolar exudate. No viral inclusions or multinucleated giant cells were noted. The bronchi and bronchioles did not exhibit pathological changes except a small increase in lymphocytes. The interstitial compartment had lympho-monocytic infiltrates and an increase of megakaryocytes [9]. Carsana et al. reported endothelial necrosis, squamous metaplasia with atypia of the bronchi, mural fibrosis, and microcystic honeycombs of lung parenchyma [10]. Copin et al. found cytoplasmic vacuolization of lung endothelial cells, organizing pneumonia within alveolar ducts, and type II pneumocyte hyperplasia [11]. Two case reports found diffusely edematous and firm parenchyma consistent with ARDS [7, 12]. Moreover, Buja et al. described findings of thickened alveolar capillaries with the presence of $\mathrm{CD} 61^{+}$pulmonary megakaryocytes that had nuclear hyperchromasia [12]. In a study reporting autopsy finding on five COVID-19 patients, severe organizing hemorrhagic pneumonitis, injuries of the septal capillaries, and red cell extravasation of alveolar spaces were found [13]. A study done by Conde et al. also found vesicular nuclei with prominent nucleoli suggestive of viral cytopathic effect, and cells with large, hyperchromatic nuclei, similar to smudge cells described in adenovirus-related pneumonitis, were also 
Fig. 1 Histologic changes from case 1. (A) Proteinaceous exudates in alveolar spaces, with granules; (B) Scattered large protein globules (arrows); (C) Intraalveolar fibrin with early organization, mononuclear inflammatory cells, and multinucleated giant cells; (D) Hyperplastic pneumocytes, some with suspected viral inclusions (arrow). Reproduced/adapted from Tian et al., with permission from Elsevier

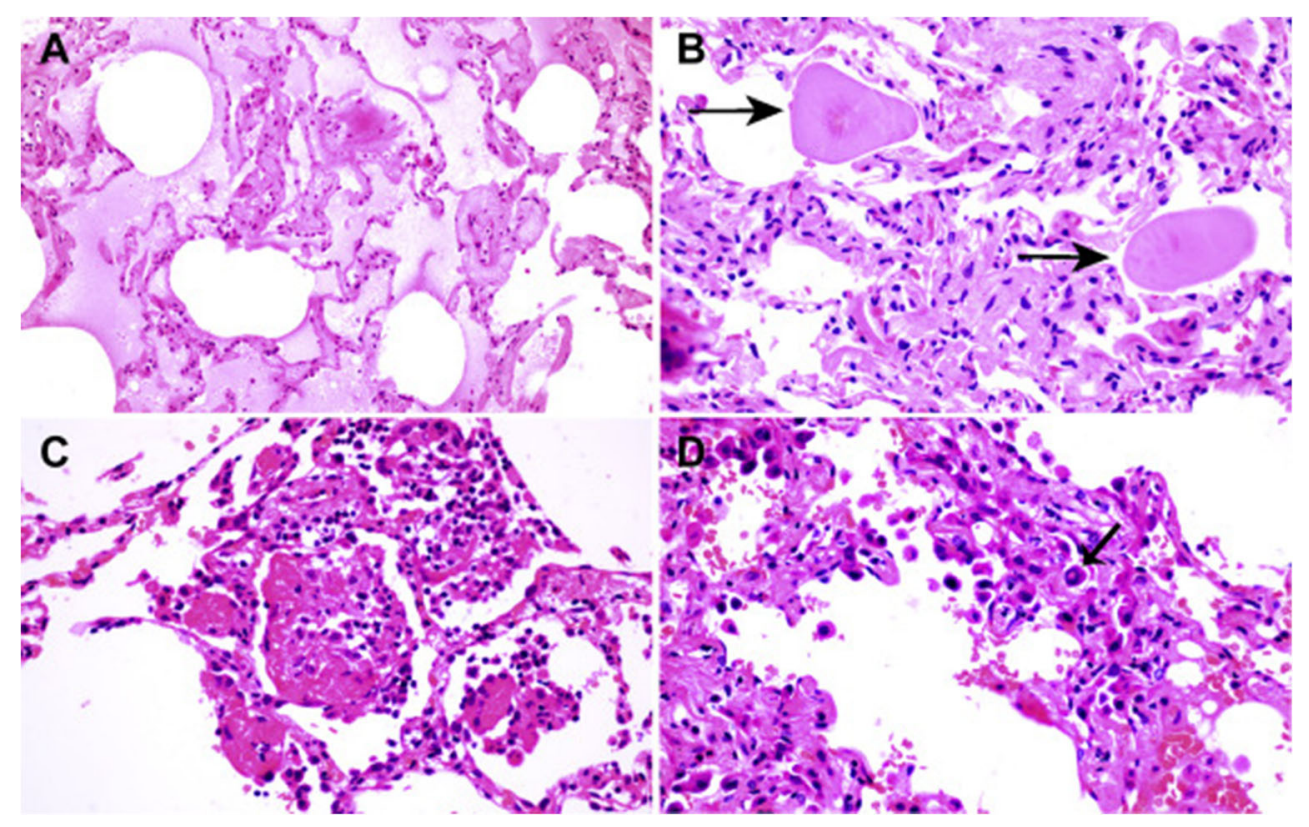

observed, along with findings similar to DAD [14]. Xu et al. reported histological changes including enlarged pneumocytes in some regions characterized by an enlarged nucleus with granular cytoplasm and prominent nucleoli showing viral cytopathic-like changes, as well as desquamation of pneumocytes in some areas [15]. Menter et al. found that approximately half of the patients in the study developed superimposed bronchopneumonia and that 4/21 patients had pulmonary embolism. They also described bluish-red in color lung parenchyma and severe capillary stasis as part of their most prominent histological findings [16]. Varga et al. found accumulation of mononuclear cells, apoptotic bodies, congestion of small vessels in the lung, and lymphocytic endotheliitis
[17]. In addition, Zeng et al. found perivascular inflammatory infiltration, interalveolar multinucleated cells, pneumocyte hyperplasia, and intracytoplasmic viral inclusions in the lung of one patient. Interestingly, they did report finding any of the common lung symptoms including DAD and hyaline membrane damage [18]. Furthermore, Pernazza et al. found prominent and diffuse neutrophil migration in septal vessels, clustering of alveolar macrophages, pneumocyte damage, and interstitial inflammatory infiltrates and diffuse hemorrhage within lung parenchyma [19]. Finally, Yao et al. described finding hyaline thrombus in microvessels, thickening of the alveolar septa, desquamation of proliferative type II AE, and exudative monocytes and macrophages [20]. There was a
Fig. 2 Histologic changes of coronavirus disease 2019 pneumonia in case 2. (A) Evident proteinaceous and fibrin exudate; (B) Diffuse expansion of alveolar walls and septa owing to fibroblastic proliferations and type II pneumocyte hyperplasia, consistent with early diffuse alveolar damage pattern; (C) Plugs of proliferating fibroblasts or "fibroblast balls" in the interstitium (arrow); (D) Abundant macrophages infiltrating airspaces and type II pneumocyte hyperplasia. Reproduced/adapted from Tian et al., with permission from Elsevier

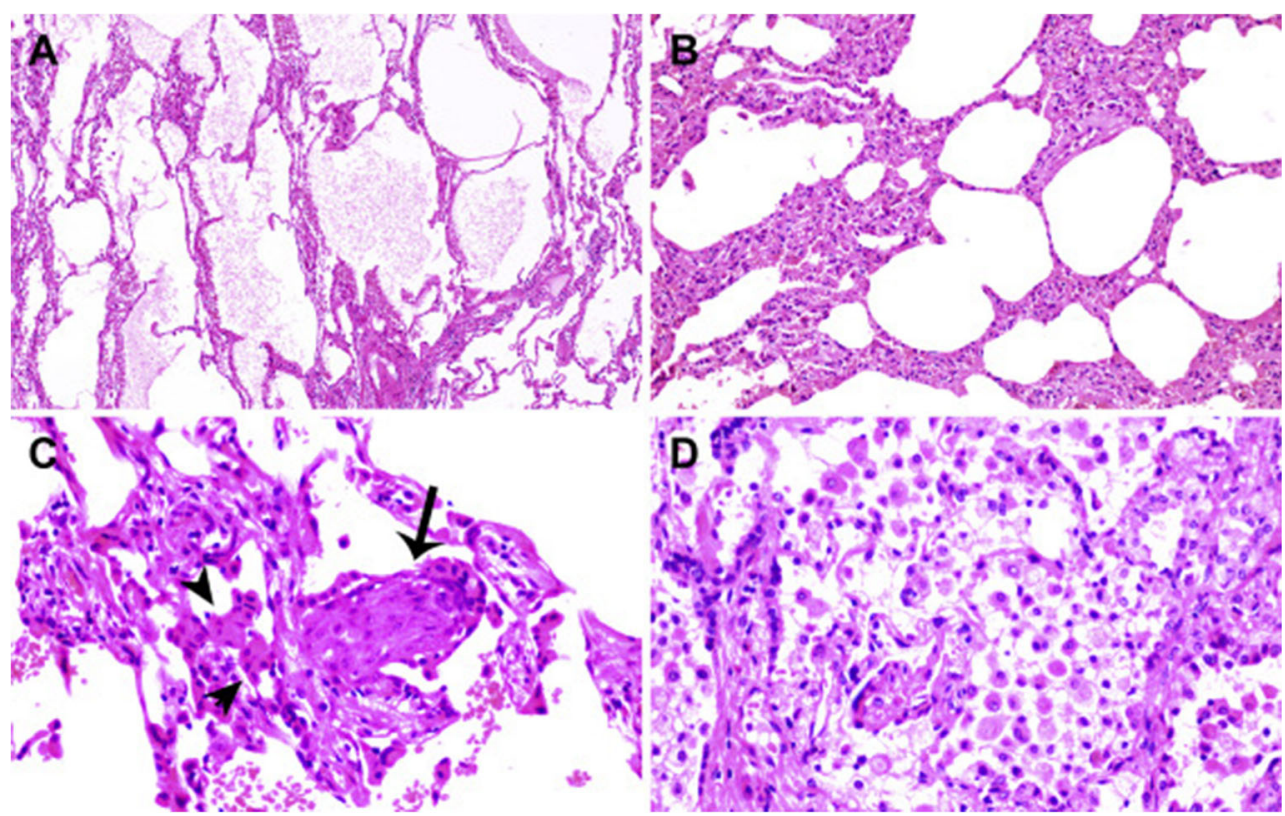




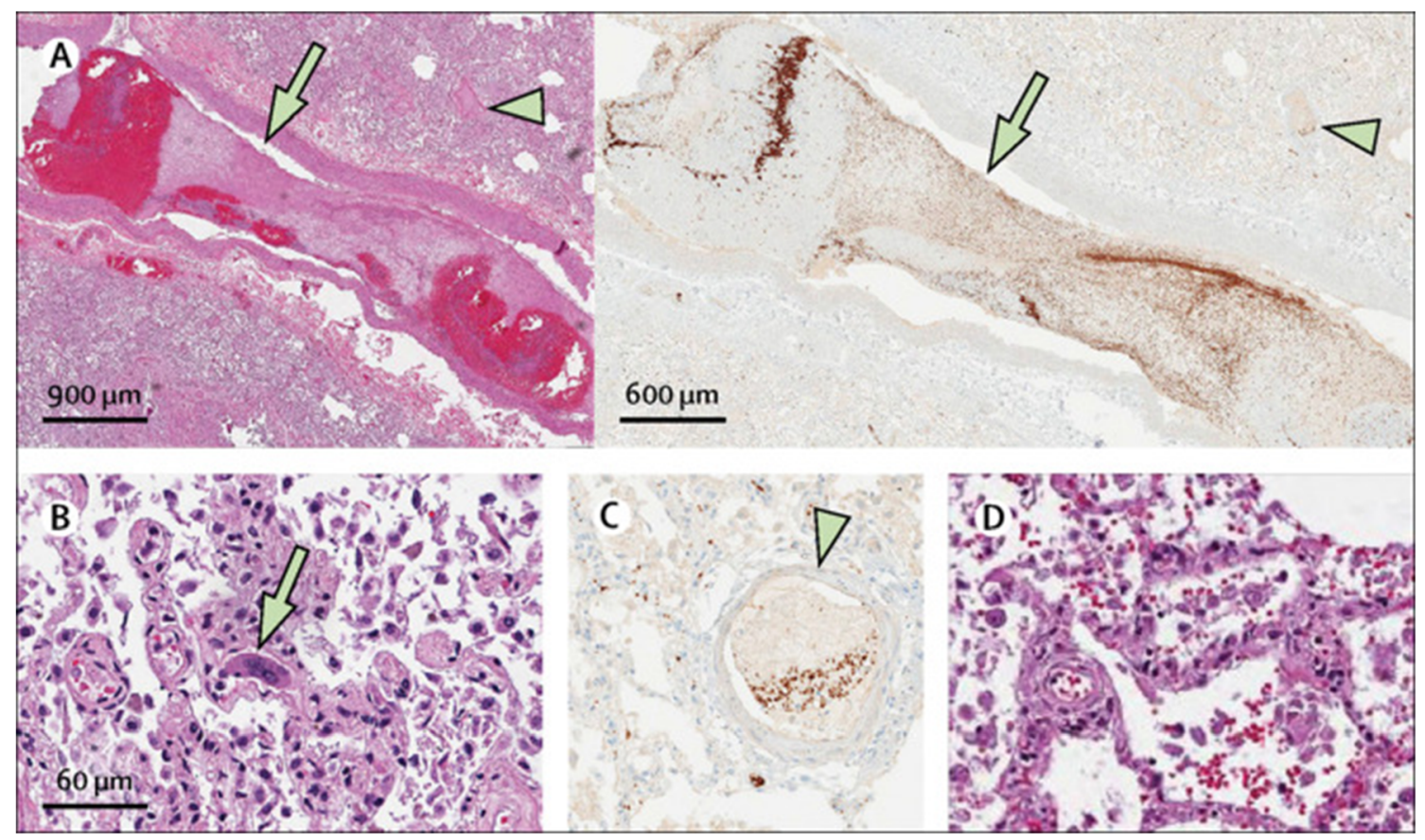

Fig. 3 Thrombus in a small pulmonary artery (green arrow), with small thrombus seen in adjacent pulmonary venule (green arrowhead), with $H \& E$ present on the left, and CD61 immunostain highlighting platelets within the thrombi on the right. (B) Many megakaryocytes were present within the small vessels and alveolar capillaries (green arrow). (C) CD61 immunostain highlighting additional fibrin and platelet thrombus shown in a small vessel, with megakaryocyte stained below (green arrowhead).
Von Willebrand factor immunostain additionally highlighted these vessels. (D) Small, perivascular aggregates of lymphocytes. Also present were small lymphocytic aggregates surrounding airways, which were positive for CD4 immunostain, with only scattered CD8 positive cells present. Reproduced/adapted from Fox et al., with permission from Elsevier
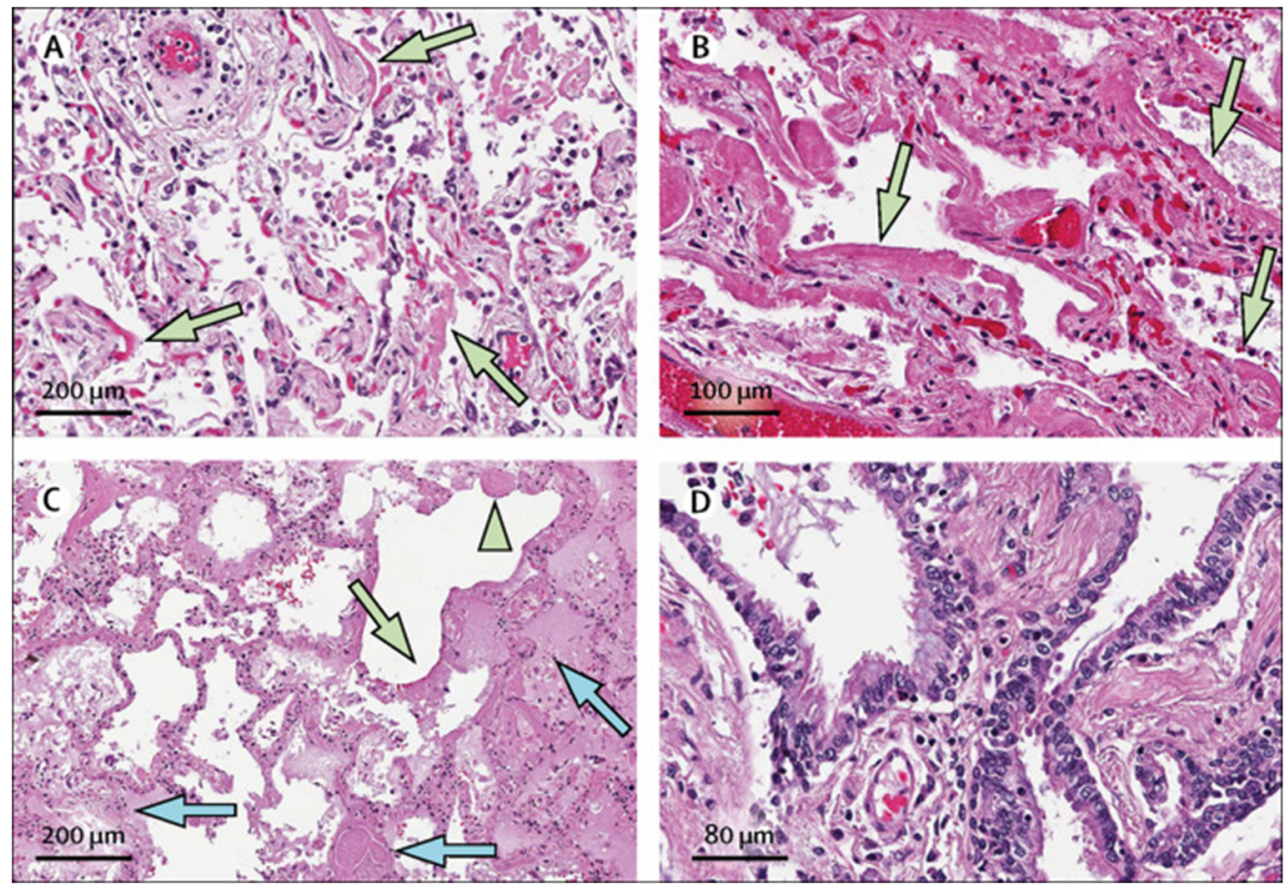

Fig. 4 All patients had extensive diffuse alveolar damage. (A) Green arrows indicate early hyaline membranes in a patient with 1 week of symptomatic illness and no mechanical ventilation (H\&E stain). (B) Green arrows indicate extensive hyaline membranes and fibrinous exudate in a patient with 9 days of symptomatic illness, including 6 days of ventilation (H\&E stain). (C) Green arrow indicates dense hyaline membranes, with organising fibrosis (green arrowhead), and fibrin thrombi

present in small vessels (blue arrows), with a pauci-immune and edematous background in a patient after 32 days of illness, including 25 days on ventilatory support. Extensive hemorrhage was also present (H\&E stain). (D) Bronchial respiratory epithelium shown with cilia present, and absence of squamous metaplasia in a patient receiving ventilatory support for 6 days. $H \& E=$ hematoxylin and eosin. Reproduced/adapted from Fox et al., with permission from Elsevier 
significant overlap within pathological findings of all of the studies that have been included in this review. The most common shared findings among lung-histological sections were DAD including hyaline membrane, edema, type II pneumocyte hyperplasia, increased macrophages, loss of cilia in epithelial cells, accumulation of fibrin deposits [5-14, 20-25], and increased lung weight [7, 12, 14].

\section{Cardiac}

SARS-CoV-2 is known to cause prominent morphological and pathological changes in the cardiac tissue. A study done on autopsies of 10 African American patients by Fox et al. showed no lesions in the myocardium and no stenosis or acute thrombosis formation on gross examination. The most significant changes found were cardiomegaly and right ventricular dilation which could lead to elevated levels of brain natriuretic peptide. The reported histological findings of this study were rare areas that showed degeneration of myocytes, but the authors could not conclude if this was the result of viral myocarditis since there was no lymphocytic inflammatory infiltrate (Fig. 5) [7]. Another study reporting autopsy finding of three COVID-19 cases by Buja et al. [12] found more cardiac changes in patients who had contracted the virus. In the first case, they found individual cardiomyocytes with degenerated vacuoles and other cardiomyocytes with enlarged hyperchromatic nuclei (Fig. 6). The histological findings of the second case showed epicardial lymphocytic infiltrates, cardiomyocyte hypertrophy, multifocal interstitial fibrosis, and scattered damaged individual cardiomyocytes, and no myocardial inflammatory foci indicative of myocarditis were seen (Fig. 7). The third case of the study exhibited multifocal lymphocytic infiltrates in the epicardium, cardiomyocytes with hyperchromatic nuclei and signs of acute injury, thickening of the coronary arteries with luminal narrowing, prominent foci of cardiomyocyte, and capillary disarray primarily in the superior portion of the interventricular septum. Additionally, Conde et al. also found increased left ventricle thickness, dilation of both ventricles, and mild stenosis in the aortic valve [14]. Bryce et al. not only had similar findings as the previous studies including an increase in cardiac mass and left ventricular hypertrophy, but also found hemophagocytosis in an area of inflamed epicardial tissue and epicardial mononuclear infiltrate of CD4/CD8 ${ }^{+} \mathrm{T}$ lymphocytes [21]. A study by Menter et al. also reported seeing senile amyloidosis, peracute myocardial necrosis, and acute myocardial infarctions in COVID-19 patients but attributed some of the symptoms to shock [16]. Finally, Suess et al. also noted the presence of nonspecific pericardial inflammatory cell aggregates such as lymphocytes and plasma cells [26]. Because most studies have had relatively small sample sizes, there has not been a set of established pathological findings of SARS-CoV-
2 , rather there has been a wide array of pathologies that have been reported.

\section{Liver and Gallbladder}

ACE2, the SARS-CoV-2-binding receptor, is highly expressed in liver cells. As a result, studies have found liver injuries marked by an increase in the enzymes aspartate aminotransferase (AST) and alanine aminotransferase (ALT) within the first week a patient contracts the virus. However, it is still in question whether the virus is directly responsible for these injuries, or if they occur due to the systemic inflammatory response as a result of SARS-CoV-2 [27]. A study by Tian et al. found pathological changes associated with the liver in four reported cases, which included mild lobular infiltration by small lymphocytes and centrilobular sinusoidal dilation, but all of the patients in this study had underlying liver conditions and many of these changes could be attributed to the presence of liver comorbidities in these patients. In addition, they found glycogen accumulation in hepatocytes and periportal and centrilobular necrosis in one of the four patients [28]. Bryce et al. found significant morphological changes in 22 COVID-19 patients including nutmeg congestion, multiple cysts, venous outflow obstruction, phagocytosed red blood cells, mild to severe steatosis, calcifications in sinusoidal spaces, and stage 3 fibrosis [21]. Menter et al. and Byrce et al. both also reported seeing nonalcoholic fatty liver disease in few of their autopsy findings [16, 21]. Furthermore, Varga et al. noted lymphocytic endotheliosis [17] and Bradley et al. reported centrilobular necrosis most likely sustained from hypoperfusion in a few of their patient tissue samples [29]. In addition, a study conducted by Buja et al. found moderate macrosteatosis (in 2/5 patients) and shrunken hepatocytes (corresponding to apoptosis) as well as lymphoplasmacytic triaditis with portal fibrosis [12]. Histologically, the gallbladder of the patients who had contracted the virus shows inflammatory infiltration and endoluminal obliteration of vessels, atrophic mucosa, hemorrhaging, and an overall hypertrophy of the gallbladder [28]. A study done by Balaphas et al. also found the presence of COVID-19 viral DNA particles in the gallbladder of a few of the analyzed patients [30].

\section{Spleen}

In their full organ system autopsy report, Zequing et al. found a wide array of pathological changes including splenic nodule atrophy, histiocyte hyperplasia, and lymphocyte reduction. In addition, they found the spleens to be congested, hemorrhagic, and lacking lymphoid follicles. Moreover, they reported seeing interstitial vessels and fibrous tissue hyperplasia in the sinuses [31]. Bryce et al. also found some pathological changes in the spleen of COVID-19 patients, and these included varying degrees of white pulp atrophy and hemophagocytic 
A
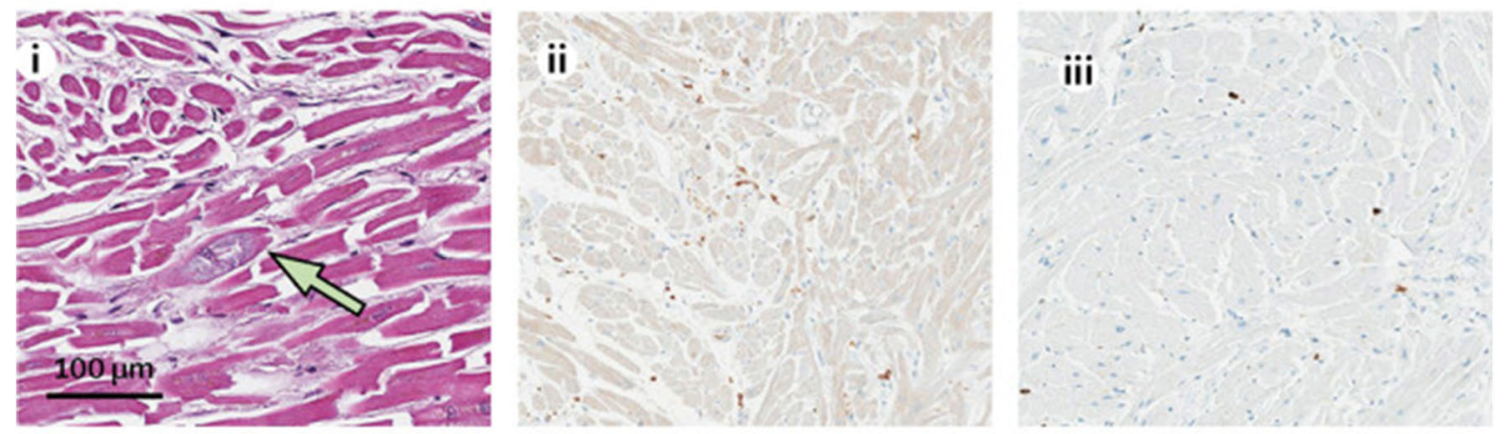

B

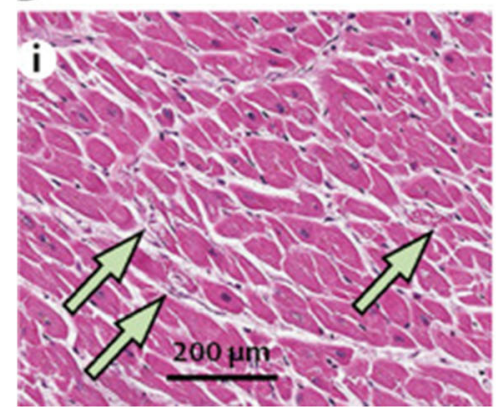

Fig. 5 Patient 2, i: cardiac myocytes, ii: CD4 immunostain, iii: CD8 immunostain. B) Patient 3, i: cardiac myocytes, ii: CD31 immunostain, iii: CD4 immunostain. Cardiac myocytes showing focal, atypical myocyte degeneration (green arrows), H\&E stain (sample images from patients aged 44- and 63-years receiving azithromycin but not hydroxychloroquine). Scant lymphocytes were present within the interstitial and endothelial spaces, with slightly more CD4+ than CD8+ cells
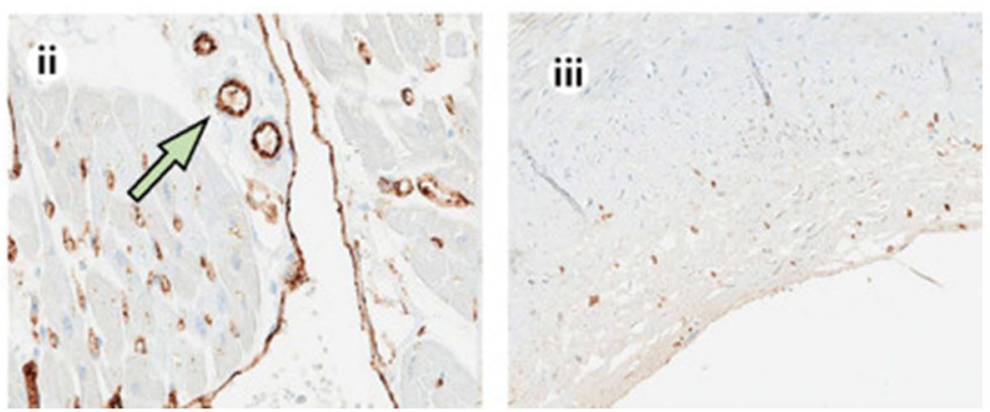

on visual inspection of immunostains. A CD31 immunostain highlighted endothelial cells, with focal prominence (green arrow) that appeared nonspecific. CD4+ lymphocytes were occasionally seen in a non-specific pattern within the coronary artery intima. $\mathrm{H} \& \mathrm{E}=$ hematoxylin and eosin. Reproduced/adapted from Fox et al., with permission from Elsevier
Fig. 6 Houston case One (HC1). (A) Epicardium exhibits a focus with lymphocytic infiltrate indicative of lymphocytic pericarditis. (B) Myocardium is edematous as manifest as separation of the cardiomyocytes (CMC) and capillaries. The CMC in the center shows vacuolar degenerative change (star). No inflammatory cells are present. (C) Liver shows moderate macro-steatosis and altered, shrunken hepatocytes likely representing incipient apoptosis. (D) Renal glomerulus with focally congested capillaries. (A, C and $\mathrm{D}$, Hematoxylin and eosin stains; B, 1-micron section, toluidine blue stain). (Magnification bar: A and C, $100 \mu \mathrm{m}$; B and D, $20 \mu \mathrm{m}$ ). Reproduced/adapted from Buja et al., with permission from Elsevier
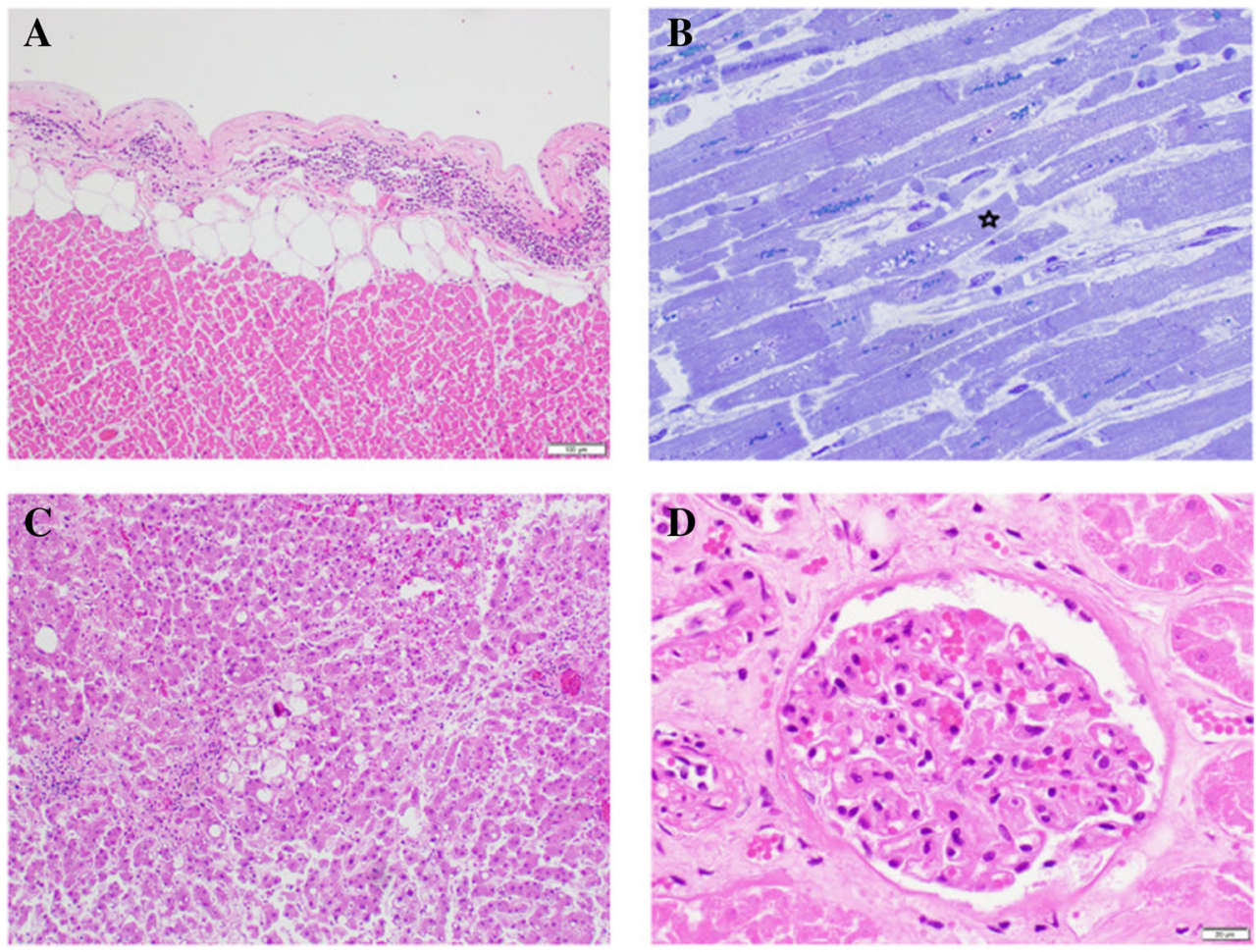
Fig. 7 Houston case Two (HC2). (A and B) Myocardium is edematous and small blood vessels are congested. The CMC exhibit multifocal vacuolar degenerative changes. No inflammatory cellular infiltrates are present. Note the increased width of these $\mathrm{CMC}$ compared to those of HCO (Fig. 6B). The patient's heart weighed $1070 \mathrm{~g}$. (C) The epicardium exhibits a lymphocytic infiltrate adjacent to a vein. (D) Testis with thrombi in peritesticular veins. (A and B, one-micron sections, toluidine blue stain; C and D, hematoxylin and eosin stains). (Magnification bar: A and B, $20 \mu \mathrm{m} ; \mathrm{C}, 100 \mu \mathrm{m}$; D $500 \mu \mathrm{m})$. Reproduced/adapted from Buja et al., with permission from Elsevier
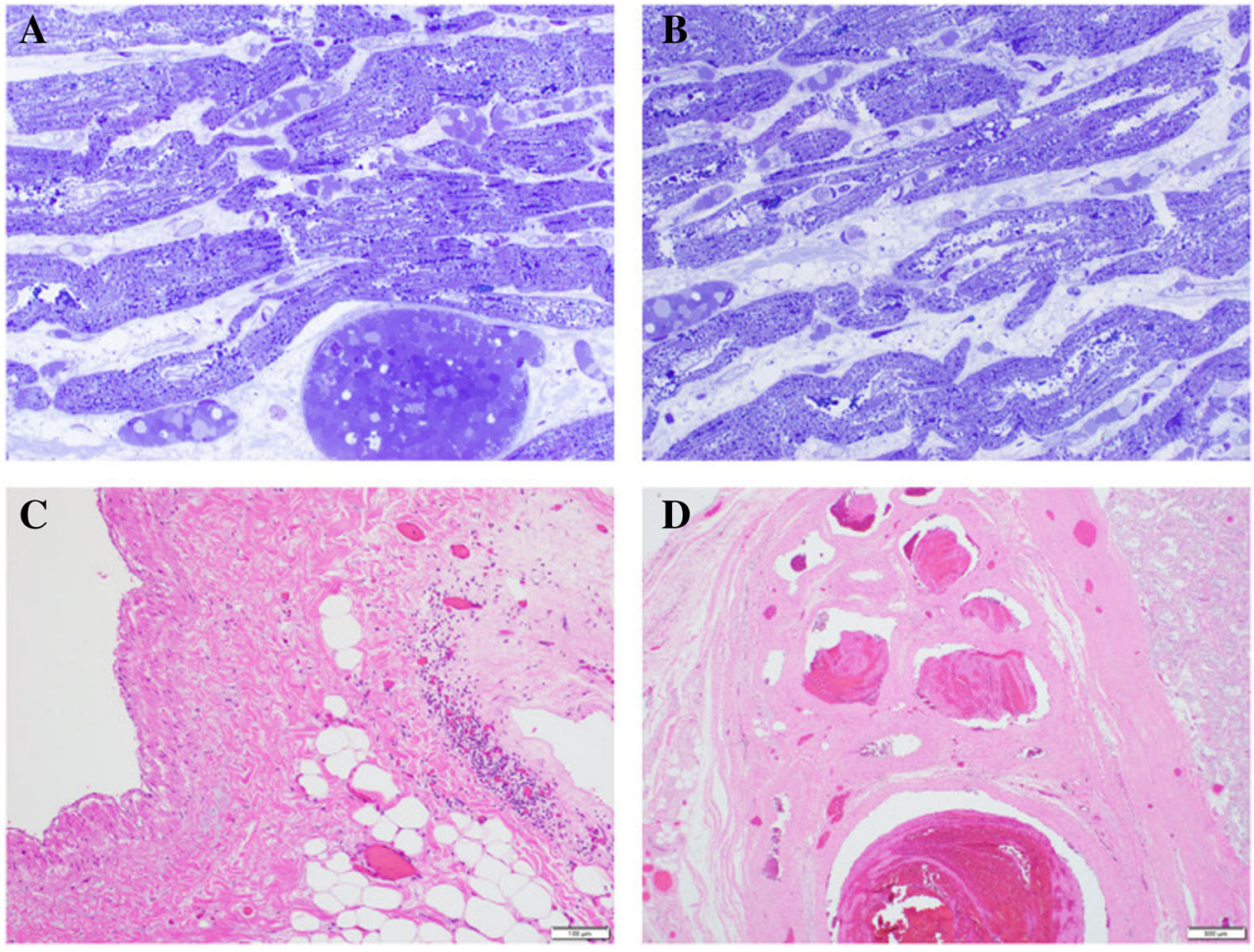

histiocytosis. Menter et al. also reported seeing acute splenitis in 6/21 patients [21]. Finally, Sekulic et al. interestingly noted that they also found high concentrations of SARS-CoV-2 RNA in the spleen [32].

\section{Kidney}

The kidneys are known to be a prominent target for SARS$\mathrm{CoV}-2$, and as a result, there is a wide array of morphological and pathologic changes in the kidneys of COVID-19 patients. $\mathrm{Su}$ et al. reported glomerular changes in patients who have contracted SARS-CoV-2 including nodular mesangial expansion and hyalinosis of arterioles, arteriosclerosis, and ischemic glomeruli. The capillaries around the glomerulus are particularly affected. It has been found that there are aggregations of erythrocytes and regions of segmental fibrin thrombi in the glomerulus areas. Also, ischemic shrinkage of capillaries leading to plasma leakage was identified. Moreover, there were also endothelial changes found around the glomerular loop including endothelial proliferation, swelling, and subendothelial lucent expansion (Fig. 8). They also found the presence of viral particles in the podocytes of the glomeruli [33]. This finding is further corroborated by Kral et al. and Sekulic et al. who also found SARS-CoV-2 particles in this region and an increased RNA expression of genes [32, 34]. Other studies have found additional pathologies in COVID patients including minimal change disease, collapsing glomerulopathies, lymphocyte infiltration [35], and severe podocytopathy $[32,36]$. In addition, Kissling et al. also noted finding cases of severe collapsing glomerulopathies, collapse of shrinking capillary loops, and hypertrophic proliferating podocytes [37].

Although the tubules do not have as many pathological changes as the glomeruli, the few changes that do occur have important clinical relevance. Distal tubules and collecting ducts show occasional swelling and there is edematous expansion of the interstitial space in some patients. The most significant changes are seen in peritubular capillaries. There is often an aggregation of erythrocytes blocking the capillaries, vascular degeneration, loss of brush border cells, dilation of the tubular lumen, acute tubular injuries, and enhanced cb5-9 deposition (Fig. 8) $[33,35]$. An ACE2 staining also showed an increase in receptors in proximal tubular cells. Coronavirus particles have been found in the renal proximal tubular epithelium and in the distal tubes (less in this region) $[33,35]$. In addition, Sekulic et al. [32] also found acute tubular necrosis and an overall increase in kidney mass. Furthermore, Buja et al. also found other pathologies including hyaline arteriolosclerosis with glomerulosclerosis, fibrin platelet thrombus in the renal glomerular capillaries, and rare occurrences of holosclerotic glomeruli necrosis. They also found the presence of viral particles in both glomerular and endothelial cells [12]. Finally, Kissling et al. noted finding intratubular reabsorption vacuoles which they said reflected heavy proteinuria [37]. 
Fig. 8 Spectrum of pathologic abnormalities of kidneys from postmortems of patients with coronavirus disease 2019. (a, b) Proximal tubules showed (a) loss of brush border and (b) vacuolar degeneration (arrows), with debris composed of necrotic epithelium in tubular lumens (asterisks). Erythrocyte aggregates

obstructing peritubular capillaries were frequently present (arrowheads). (c, d) Some cases showed infiltration of inflammatory cells in (c) tubules and (d) in 1 case, in an arcuate artery (arrows), with multiple foci of bacteria (asterisks) and white blood cell casts (arrowhead). (e, f) Occasional (e) hemosiderin granules and (f) deposits of calcium (arrowheads) were present in tubules with occasional pigmented casts (arrows). (g, h) Segmental fibrin thrombi were present in glomeruli (arrowhead), with ischemic glomerular contraction (arrows) with the accumulation of leaked plasma in Bowman's space (asterisks). Hematoxylin and eosin. Bars = (f) $50 \mu \mathrm{m},(\mathrm{a}-$ am) $100 \mu \mathrm{m}$, and (d) $250 \mu \mathrm{m}$. Reproduced/adapted from $\mathrm{Su}$ et al., with permission from Elsevier
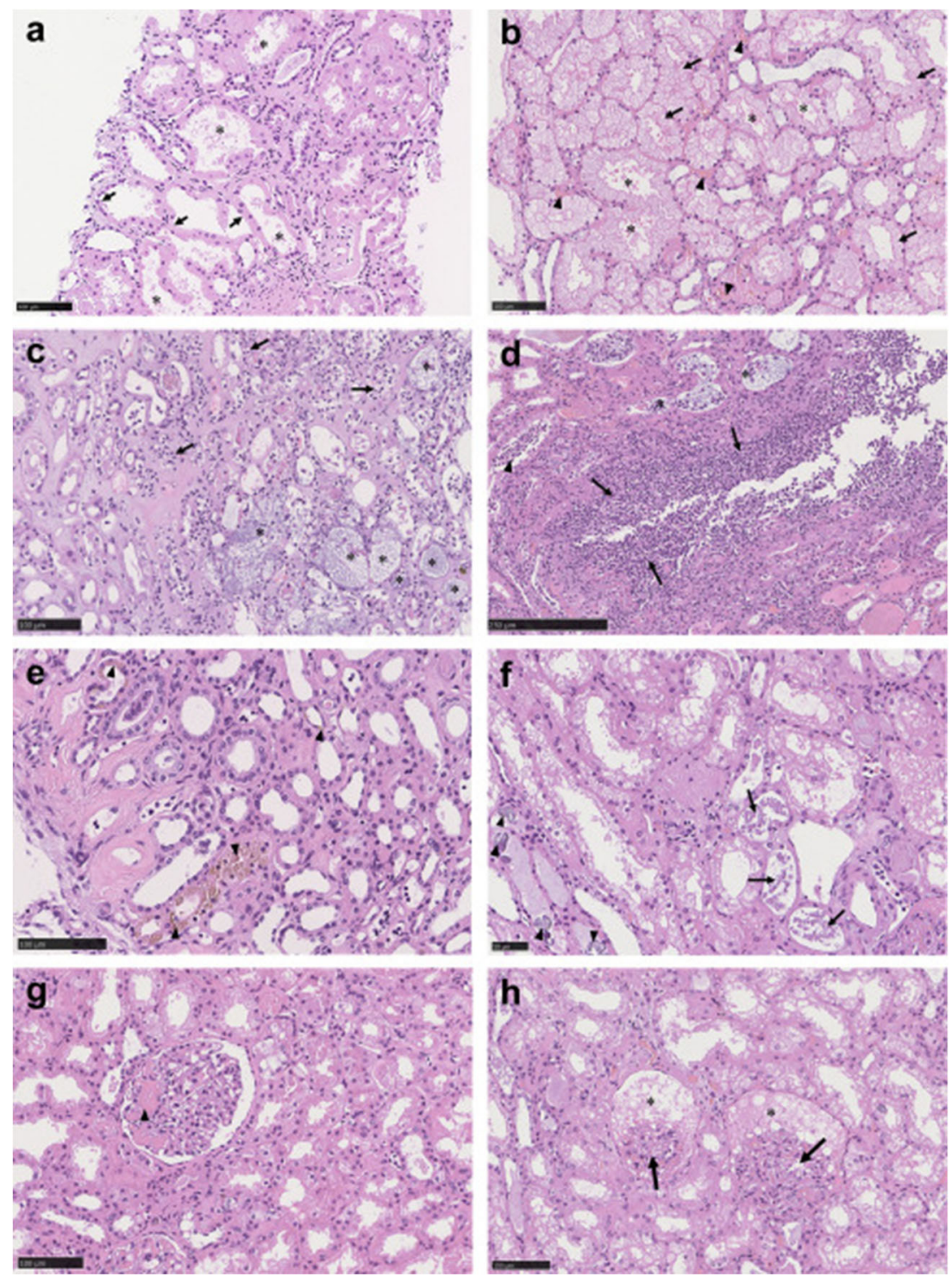

\section{Brain}

Recent emerging literature has reported headache, anosmia, and confusion as the common symptoms of COVID-19 infection $[3,38]$. Solomon et al. performed autopsies of brain specimens from 18 confirmed COVID-19 patients. Some common histological findings among these patients were that their cerebrum and cerebellum showed hypoxic changes and they had loss of neurons in the cerebral cortex, hippocampus, and cerebellar Purkinje layer but no thrombi. Gross inspection showed atherosclerosis in $14 / 18$ brain specimens with no symptoms of acute stroke. The SARS-CoV-2 virus, however, was detected in $6 / 18$ patients' brain tissue samples [39]. This result is further corroborated by a case report published by Paniz-Mondolfi et al. in which they found the presence of SARS-CoV-2 particles in a patient's brain and capillary endothelium (Fig. 9) [40]. Additional findings regarding the pathophysiology of SARS-CoV-2 have also been presented in a case report published by Riechard et al. They found hemorrhaging of white matter (Fig. 10) (through staining for myelin) which they described as having a disseminated encephalomyelitis (ADEM)-like appearance, primarily the result of intraparenchymal blood. Moreover, there was a clustering of macrophages, axonal injuries, and necrosis in microscopic areas of neocortical organizing regions. In addition, they found perivascular cellular infiltrates, graduated myelin loss, terminal hypoxic-ischemic injury characterized by the presence of scattered necrotic neurons in the hippocampus and cerebellum, and varying degrees of axonal injuries scattered throughout the brain (Fig. 11) [41]. Furthermore, while most of the brain samples analyzed by Bradley et al. showed no remarkable changes, there were a few samples that showed interesting pathological changes including subarachnoid hemorrhages and microhemorrhages in the brain [29]. The most 


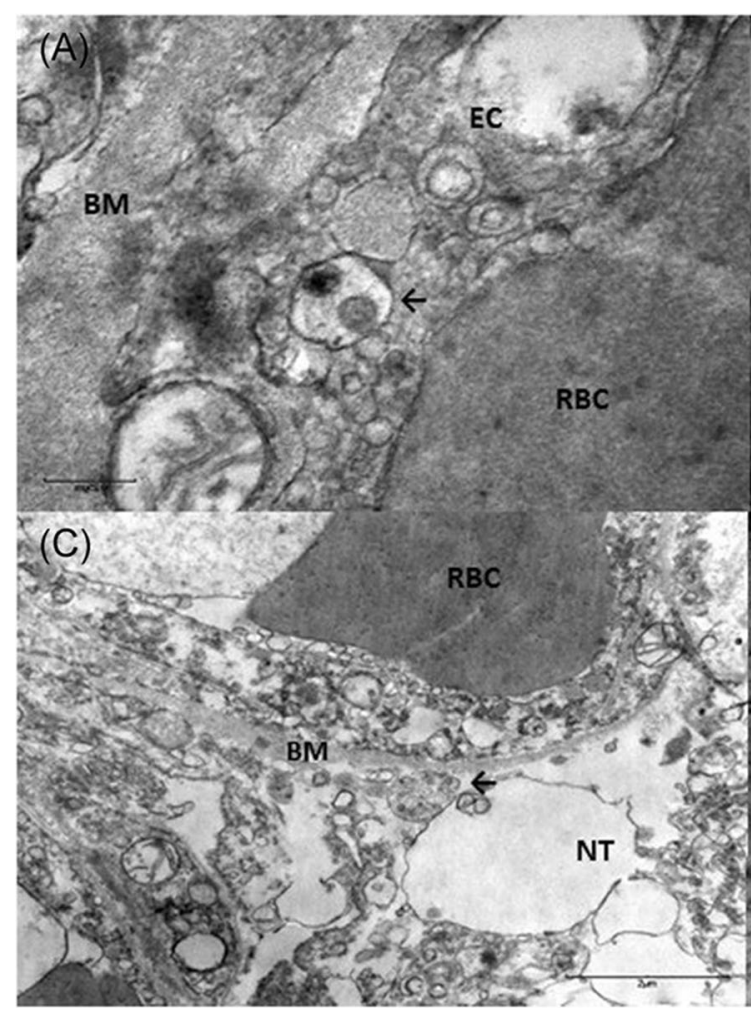

Fig. 9 A, Brain capillary endothelial cells showing virus particles within cytoplasmic vacuoles ( $\leftarrow$ arrow). B, Blebbing of viral particles coming in/out of the endothelial cell wall (circles) The relationship of virus particles (arrows $\longleftarrow$ ) to the endothelial cells (virus ingress/egress) is depicted. Note the dense inner core and densely stained periphery of viral particles. $\mathrm{C}$, Endothelial neural cell interface showing a cytoplasmic vacuole filled with viral particles in various stages of bud formation (arrow $\longleftarrow$ ) adjacent to the basement membrane within the neural cell (frontal lobe). D, Neural

striking findings in 20 neuropathological cases reported by Bryce et al. were the widespread and variable presence of microthrombi and acute infarction (6/20). Only one case showed a large cerebral artery territory infarct, 3 cases showed small and patchy peripheral and deep parenchymal ischemic infarcts, and others were hemorrhagic. They also noticed outof-proportion vascular congestion which was occasionally accompanied by acute parenchymal microhemorrhages, especially within the necrotic area of infarction, suggestive of vascular damage and reperfusion injury [21].

\section{Skin}

- A study conducted by Magro et al. reported findings on the skin of five COVID-19 death cases. The most common finding reported was purpuric skin rash found on the buttocks, limbs, and chest which showed pauciinflammatory thrombogenic vasculopathy. Some patients also had inflammation of areas around the skin rashes. There were other rarer findings reported including a superficial vascular ectasia, occlusive arterial thrombus, and extensive vascular deposits of C5b-9, C3d, and C4d

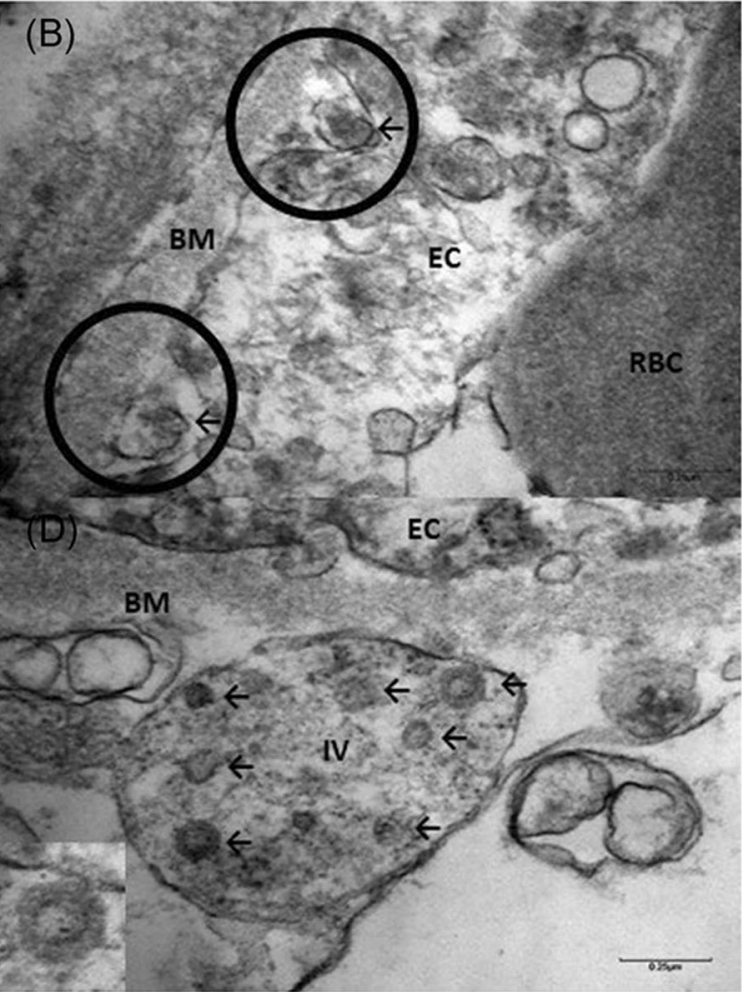

intracytoplasmic vesicle showing viral-like particles. Insert: Detail on viral particle exhibiting electron dense centers with distinct stalk-like peplomeric projections. Scale bars are shown at the bottom left/right of each figure. BM, basement membrane; EC, endothelial cells; IV, intracytoplasmic vesicles; NT, neural tissue; RBC, red blood cell. Reproduced/adapted from Mondolfi et al., with permission from John Wiley and Sons

throughout the dermis. Additionally, perivascular lymphocytic infiltrates in the superficial dermis and small thrombi venules in the deep dermis were reportedly found in one of the patients [13]. Furthermore, Gianotti et al. described seeing widespread erythema ranging from the chest to the legs that spontaneously disappeared on three separate COVID-19 patients. All three patients had superficial perivascular dermatitis and varying degrees of vessel damage. One of the three patients exhibited more severe pathologies including swollen vessels in the dermis with lymphocyte infiltration and a few necrotic patches of keratinocytes [42]. Finally, Fernandez-Nieto et al. reported finding that some patients with COVID-19 present with various rashes including unspecific maculopapular rash and urticaria [43].

\section{Eyes}

Usually the tear ducts/eyes are thought of as potential transmission points for viruses. Viruses such as the adenovirus have been known to have highly contagious 
Fig. 10 a-d Microscopic sections of the corpus callosum genu. a $H \& E$ section of destructive hemorrhagic white matter lesion. b H\&E section with white matter pallor adjacent to hemorrhagic lesion with GFAP

immunoreactive reactive astrocytes evenly distributed in the white matter (inset) c CD68 immunostaining highlights a collection of macrophages at the periphery of the hemorrhagic lesion and a macrophage within an area of white matter pallor. d APP immunostain identifies axonal swellings within the hemorrhagic lesion and an absence of damaged axons within adjacent region of demyelination. e, f LFB/PAS stain distinguishes the focal area of myelin loss within the hemorrhagic lesion and adjacent PASpositive foamy macrophages tracking along blood vessels and (f) higher magnification of the perivascular macrophages. Reproduced/adapted from Reichard et al. (open access article), with permission from Springer Nature
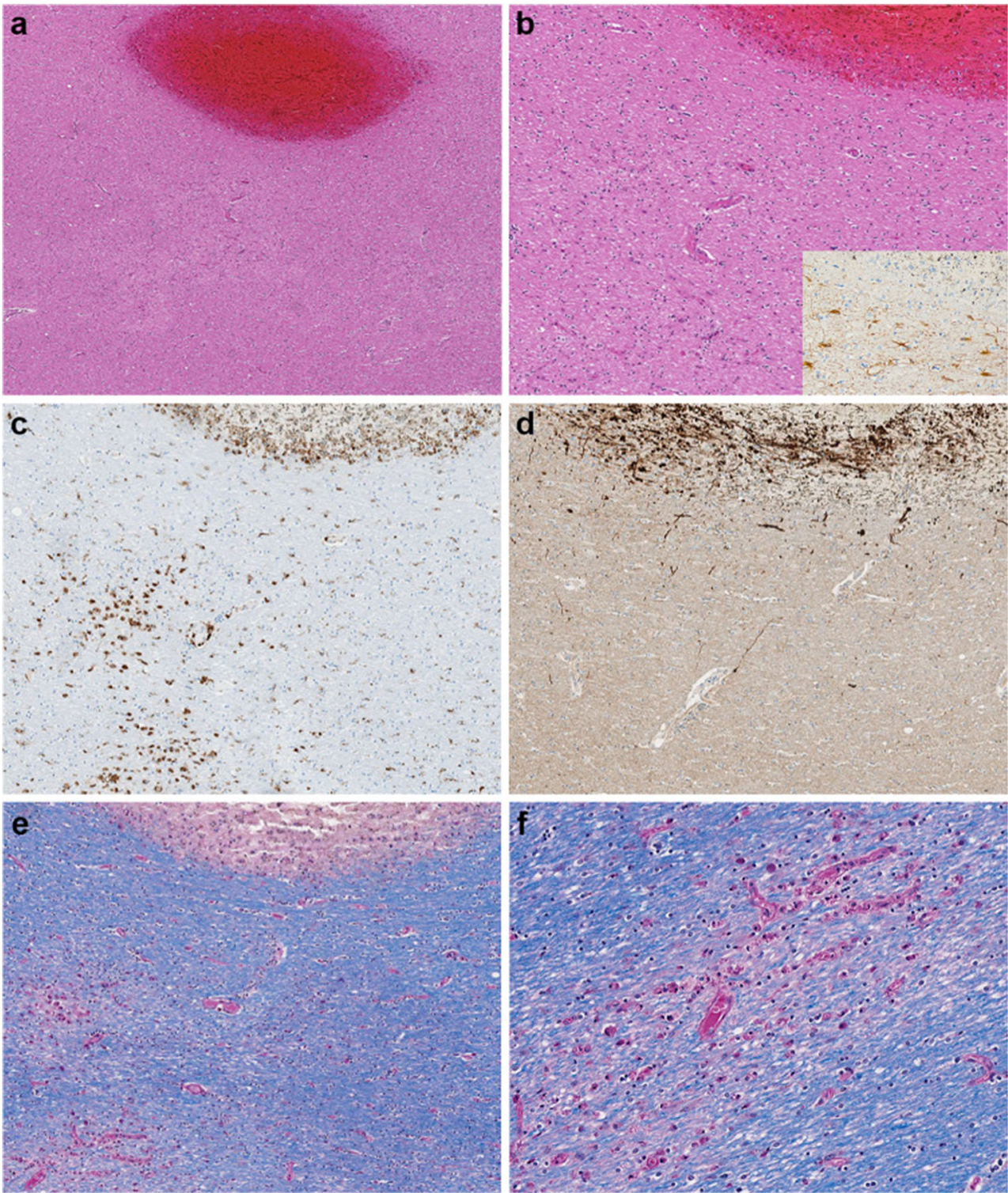

keratoconjunctivitis epidemica, and it was thought that this could potentially be a mode of transmission for SARS-CoV2 as well. Moreover, the eyes could also theoretically allow for an entry point for the virus since they have ACE2 receptors (SARS-CoV-2-binding receptors). However, in a study that analyzed ocular samples from three patients, researchers did not find any trace of the virus or any pathologies that could have been attributed to SARS-CoV-2 [44]. One of the limitations of this study was its small sample size (only 3 patients). Another study that analyzed 14 patients actually did find the presence of SARS-CoV-2 viral RNA in the retina of 3/14 patient samples; however, they did not analyze or mention the ocular pathologies that could have been associated with the virus [45]. Although conjunctivitis has been found among COVID-19 patients and was reported as a symptom in patients in both above studies [44, 45], conjunctivitis can be considered one of the presenting symptoms and needs further evaluation in the setting of the COVID-19 pandemic. However, the vast majority of conjunctivitis results from viral infections, and so this symptom should not be a primary factor of evaluation when diagnosing a patient with COVID-19.

\section{Placenta}

One of the first studies that analyzed the effects of SARS$\mathrm{CoV}-2$ on a placenta found that among the three patients studied there was an overall increase in both fibrin deposit and syncytial nodule size. Two out of the three placentas analyzed showed irregular pathology with one having massive infarction and the other a chronic hemangioma [46]. Although there have only been a few studies on this subject, the findings among them have been fairly consistent. A second study 
Fig. 11 a) H\&E section of subcortical white matter with perivascular pallor. b LFB/PAS stained section demonstrates the perivascular myelin loss within the subcortical white matter lesion. c CD68 immunostain confirms the perivascular distribution of the macrophages. $d$ APP immunostain highlighting some damaged axons present in the region of myelin loss. e LFB/PASstained section of middle cerebellar peduncle with a central destructive lesion and radiating graduated myelin loss. f APP immunostained section of middle cerebellar peduncle lesion highlighting the marked axonal injury. Reproduced/adapted from Reichard et al. (open access article), with permission from Springer Nature
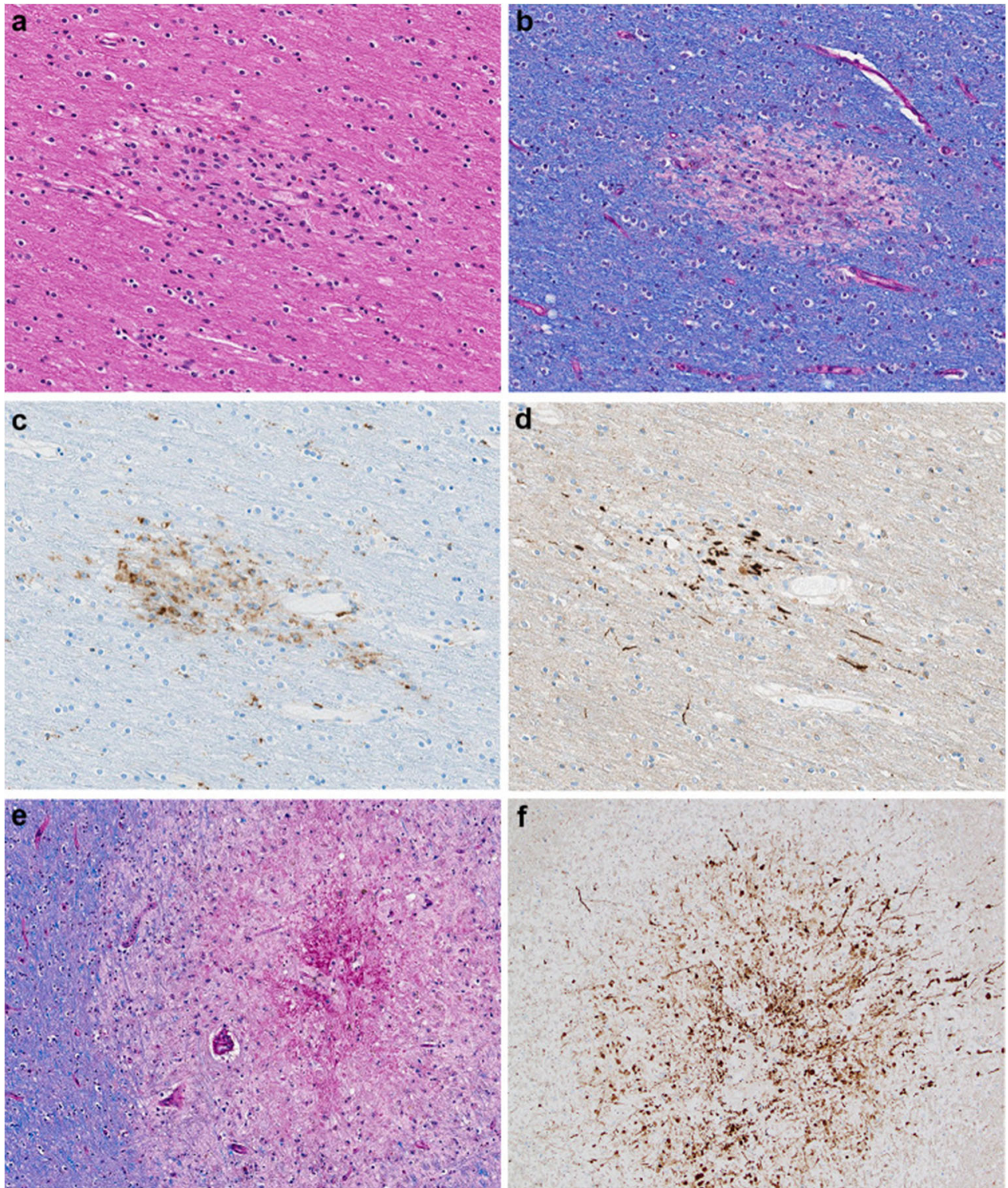

conducted by Shanes et al. that examined the placenta of fifteen women showed that women who have the SARS-CoV-2 virus are more likely to have symptoms of vascular malperfusion such as basal plate with adherent myometrial fibers, intervillous thrombi, increased perivillous fibrin deposition, and abnormal formation or injury to maternal villi. This study also found that there was an increase in circulating nucleated red blood cells [47]. Another study conducted by Baergen that analyzed the placenta of 20 mothers also yielded similar findings: fetal vascular malperfusion and thrombosis as well as an increased intramural fibrin deposits and avascular villi (a rare finding) (Figs. 12, 13, and 14). This study also brought up the idea that, although it is not commonly seen, SARS-CoV-2 can have a vertical pattern of inheritance [48]. Because of the limited number of studies on this subject and the fact that a lot of the findings have only been considered "low-grade lesions," the true effect of SARS-CoV-2 on pregnant mothers is relatively unknown.

\section{Discussion: COVID-19, SARS, and Middle East Respiratory Syndrome}

Since SARS-CoV-2 has only recently emerged as a pandemic, there has not been an established set of pathological findings associated with the virus. Pathologists have been working to examine autopsy reports and histological slides of tissues in order to determine the histopathologic features of the virus. However, there have been varying reports in the literature where one study finds one set of pathological changes in an organ and another study finds a completely different set of 


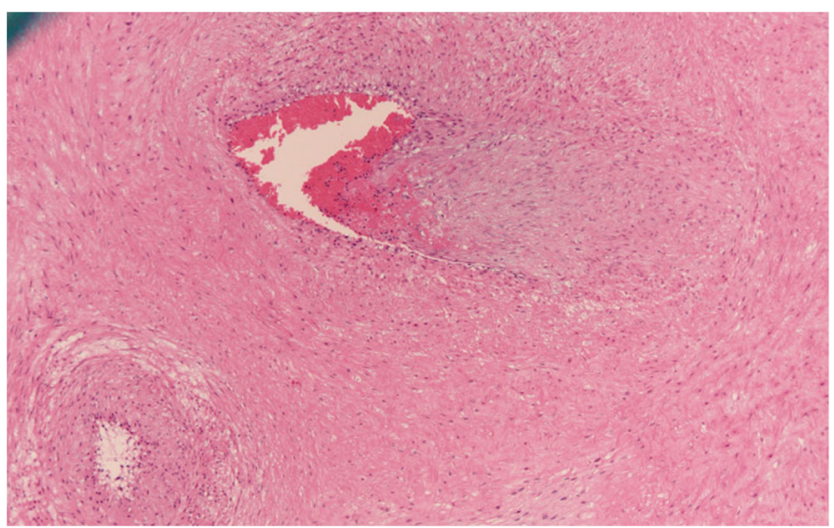

Fig. 12 Section of a stem vessel in the placenta showing fetal vascular malperfusion, specifically intramural fibrin deposition where fibrin is deposited in the intima of the vessel. This was the most common type of thrombotic lesion in these placentas. H\&E original magnification $200 \times$. Reproduced/adapted from Baergen et al. (open access article), with permission from Sage Publisher

changes. This is perhaps due to the fact that most studies only analyzed a small number of autopsies (3-5) due to the risk of pathologists contracting SARS-CoV-2. Hence, it is difficult to see consistent pathological changes. The few significant findings which the literature has reported so far are further complicated by the fact that patients who died due to COVID-19 often have underlying comorbidities that may also have led to these pathological changes. Therefore, in this scenario, the literature review studies looking at the trends as well as the unique findings across an encompassing array of studies can help in understanding the most prevalent and exceptional changes. In our review, we found and reported consistent pathologies associated with some of the organ systems as well as some unique findings (Table 1).

As discussed above, the common pathological changes in the lungs reported by many studies were DAD including hyaline membrane formation, edema, type II pneumocyte hyperplasia, increased macrophages, loss of cilia in epithelial cells,

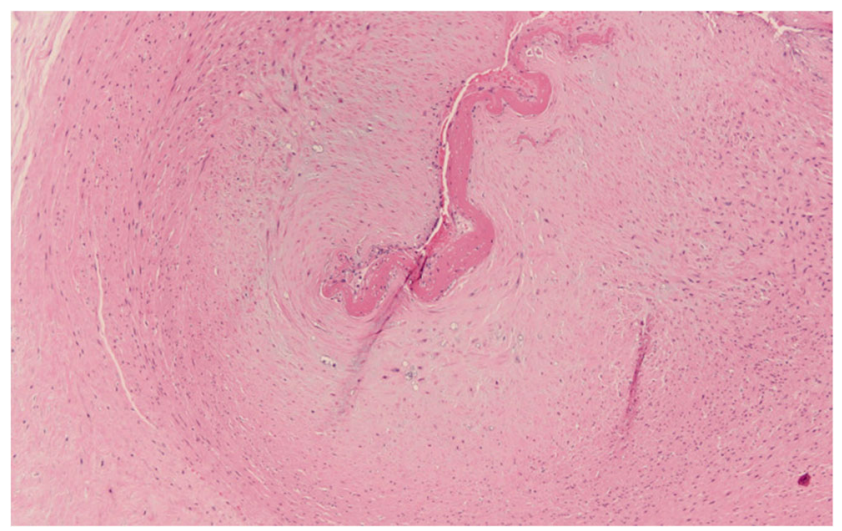

Fig. 13 Section of a chorionic plate vessel showing fetal vascular malperfusion, also with deposition of fibrin in the intimal of the vessel extending into the lumen. H\&E original magnification $100 \times$. Reproduced/adapted from Baergen et al., (open access article) with permission from Sage Publisher

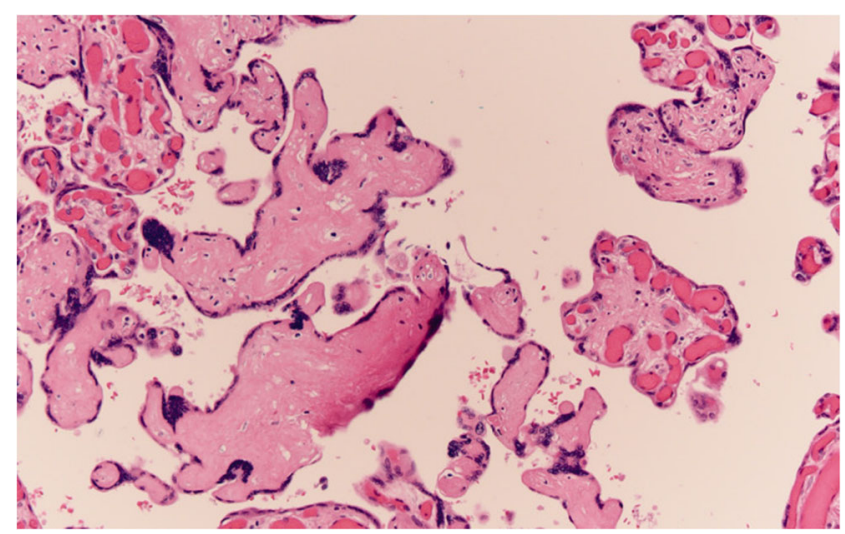

Fig. 14 Section of chorionic villi which are avascular. This is another lesion of fetal vascular malperfusion which develops due to thrombosis upstream from the chorionic villi leaving to loss of fetal circulation downstream from the thrombosis. Loss of circulation ultimately leads to loss of fetal vessels with preservation of surface trophoblast. Here, the villi are avascular and the stroma is hyalinized. H\&E original magnification 400×. Reproduced/adapted from Baergen et al. (open access article), with permission from Sage Publisher

accumulation of fibrin deposits, and increased lung weight. There are many overlapping lung pathologies between SARS-CoV-2 and SARS-CoV and Middle East respiratory syndrome (MERS) patients. Similar to SARS-CoV-2, the pathological findings of SARS include heavy lungs (up to $2100 \mathrm{~g}$ ), edema, DAD, hyaline membrane damage, increased interstitial lymphocytes, and alveolar macrophages. There has also been RNA of the SARS virus detected through immunofluorescent hybridization in the lungs of patients who had contracted the virus [49]. An autopsy performed by $\mathrm{Gu}$ et al. also noted the presence of fluid-filled alveoli, desquamated alveolar bronchial epithelial cells, alveolar epithelial hyperplasia, small vessel vasculitis, edema, and hemorrhaging in the lungs of deceased SARS patients [50]. Furthermore, studies have reported other SARS pathologies including loss of cilia, squamous metaplasia, giant cell infiltrate [51], acute inflammatory exudates, atypical pneumocytes characterized by eosinophilic nuclei, and a granular amphophilic cytoplasm as well as the formation of granulation tissues in small airways [52]. Finally, Nicholls et al. also reported many similar findings but included seeing fibrin thrombi, giant cell formation in the alveolar lumen, swelling of pulmonary vessels, and diffuse amounts of lung parenchyma [53]. Unlike the low case fatality rate for any type of the SARS-CoV virus (around 2-5\%), the case fatality rate for MERS is significantly higher (around $35 \%$ ). This difference in mortality rates between viruses is striking since MERS also causes many of similar pathologies seen in SARS-CoV and SARS-CoV-2 such as diffuse alveolar damage, necrotizing pneumonia, infections in pneumocytes, epithelial cells, and bronchial submucosal glands [49, 54]. While the autopsy data of SARS and MERS are relatively limited compared to SARS-CoV-2, there is a clear consensus 
Table 1 Characteristics of studies and their gross and histopathological findings

\begin{tabular}{lllllll}
\hline Author & $\begin{array}{c}\text { Sample } \\
\text { size }(n)\end{array}$ & Age & Sex $(n)$ & Comorbidities & $\begin{array}{c}\text { Organ } \\
\text { system }\end{array}$ & Gross findings \\
\hline $\begin{array}{c}\text { Tian et al., China } \\
{[6]}\end{array}$ & 2 & $\begin{array}{c}84 \text { and } \\
73\end{array}$ & M and F & Lung adenocarcinoma & Lung & $\begin{array}{c}\text { 1.2-cm and 1.5-cm masses in } \\
\text { the lung }\end{array}$
\end{tabular}

COVID-19-related

histological findings [6] 73

Fox et al., USA $10 \quad 44-78 \quad$ M: 10

[7]

$\begin{array}{cccccc}\begin{array}{c}\text { Zhang et al., } \\ \text { China [8] }\end{array} & 1 & 72 & \text { M } & \text { DM and HTN } & \text { Lung } \\ & & & & \\ \text { Barton et al., } & 2 & \begin{array}{c}77 \text { and } \\ \text { USA [25] }\end{array} & \text { M } & \begin{array}{c}\text { Hypertension, } \\ \text { splenectomy, } \\ \text { myotonic } \\ \text { dystrophy }\end{array} & \text { Lung } \\ & & 42 & & & \end{array}$

HTN, DM2, CKD 3, Lung and CHF, OSA, COPD, heart and atrial

fibrillation
Lung: The parenchyma was diffusely edematous and firm, consistent with ARDS. Dark-colored hemorrhagic regions with focal demarcation throughout the peripheral parenchyma. Small, firm thrombi in sections of the peripheral parenchyma

Heart: cardiomegaly and right ventricular dilatation

N/A

Case 1: alveolar edema and proteinaceous exudates, focal fibrin clusters mixed with mononuclear inflammatory cells, and multinucleated giant cells. No significant neutrophil infiltration. Patchy and severe pneumocyte hyperplasia and interstitial thickening; suspected viral inclusions

Case 2: proteinaceous and fibrin exudates, thickened alveolar walls, proliferating interstitial fibroblasts, and type II pneumocyte hyperplasia. Focal fibroblast plugs and multinucleated giant cells, indicating varying degrees of proliferative phase of diffuse alveolar damage (DAD)

Lung: bilateral DAD, pulmonary microthrombi and early hyaline membrane formation, foci of hemorrhage and fibrinous DAD

Scattered individual cell myocyte necrosis but there was no significant brisk lymphocytic inflammatory infiltrate suggestive of viral myocarditis

Revealed DAD, organizing phase and reactive type II pneumocyte hyperplasia, and intra-alveolar loose fibrous plugs of organizing pneumonia were noted

Case 1: bilateral heavy lungs, red to maroon in color edematous parenchyma that had a diffusely firm consistency without focal lesions

Case 2: bilateral heavy lungs. The red/tan mottled pulmonary parenchyma, and both lower lobes had a diffusely saturated dark red appearance

Case 1: DAD in the acute stage, thrombi within a few small pulmonary artery branches. Congestion of alveolar septal capillaries and edema fluid within the airspaces were noted focally

Case 2: foci of acute bronchopneumonia along with rare aspirated food particles. There was filling of peribronchiolar airspaces by neutrophils and histiocytes. There was no evidence of DAD, mucus plugging within airways, or eosinophils 
Table 1 (continued)

\begin{tabular}{|c|c|c|c|c|c|c|}
\hline Author & $\begin{array}{l}\text { Sample } \\
\text { size }(n)\end{array}$ & Age & $\operatorname{Sex}(n)$ & Comorbidities & $\begin{array}{l}\text { Organ } \\
\text { system }\end{array}$ & Gross findings \\
\hline $\begin{array}{l}\text { Reichard et al., } \\
\text { USA [41] }\end{array}$ & 1 & 71 & M & $\begin{array}{l}\text { Ischemic heart disease } \\
\text { (IHD) }\end{array}$ & Brain & $\begin{array}{l}\text { Mild brain swelling and } \\
\text { hemorrhagic lesions } \\
\text { disseminated throughout } \\
\text { cerebral hemispheric white } \\
\text { matter, ranging in size from } \\
1 \mathrm{~mm} \text { to } 1 \mathrm{~cm}\end{array}$ \\
\hline
\end{tabular}

COVID-19-related

histological findings

White matter disrupted by foci of intraparenchymal blood, with macrophages at the periphery of the lesions, loss of myelin,

PAS-positive macrophages, fragmented axonal processes within these lesions and oligodendrocyte apoptosis surrounding the lesions. Perivascular cellular infiltrates as macrophages, no to moderate axonal injury

\begin{tabular}{|c|c|c|c|c|c|}
\hline $\begin{array}{c}\text { Shanes et al., } \\
\text { USA [47] }\end{array}$ & 16 & N/A & N/A & N/A & Placenta \\
\hline $\begin{array}{l}\text { Su et al., China } \\
\text { [33] }\end{array}$ & 26 & 69 & $\begin{array}{l}\text { M: } 19 \\
\text { F: } 7\end{array}$ & $\begin{array}{l}\text { HTN, DM2, } \\
\text { malignancy }\end{array}$ & Kidney \\
\hline $\begin{array}{l}\text { Baergen et al., } \\
\text { USA [48] }\end{array}$ & 20 & N/A & N/A & N/A & Placenta \\
\hline $\begin{array}{l}\text { Chen et al., } \\
\text { China [46] }\end{array}$ & 3 & N/A & N/A & N/A & Placenta \\
\hline
\end{tabular}

Peripheral infarctions, decidual arteriopathy, atherosis and fibrinoid necrosis, and mural hypertrophy

Prominent proximal acute tubule injury (ATI) manifested as loss of brush border, vacuolar degeneration, dilatation of the tubular lumen with cellular debris, and occasionally even frank necrosis and detachment of epithelium with bare tubular basement membrane noted

Low-grade fetal vascular malperfusion, intramural fibrin deposition, and intramural nonocclusive thrombi which were very recent

Various degrees of fibrin deposition inside and around the villi with local syncytial nodule increases in all cases. One case showed the concomitant morphology of chorionic hemangioma and another one with massive placental infarction

\begin{tabular}{|c|c|c|c|c|c|c|}
\hline $\begin{array}{l}\text { Aguiar et al., } \\
\text { Switzerland } \\
\text { [9] }\end{array}$ & 1 & 31 & $\mathrm{~F}$ & Morbidly obese & Lungs & $\begin{array}{l}\text { Heavy grossly firm and } \\
\text { rubbery, with B/L hemor- } \\
\text { rhagic edema, tracheobron- } \\
\text { chial and pleural effusion, } \\
\text { petechiae of the skin, and } \\
\text { signs of shock, heteroge- } \\
\text { neous areas of whitish con- } \\
\text { solidation without any pu- } \\
\text { rulent discharge }\end{array}$ \\
\hline
\end{tabular}

Alveolar edema, DAD in its exudative phase with the presence of hyaline membranes, fibrin deposit within alveoli, and moderate type II pneumocyte hyperplasia which were mainly desquamated. There were moderate amounts of intra-alveolar macrophages and only scant polymorphonuclear neutrophils 
Table 1 (continued)

\begin{tabular}{|c|c|c|c|c|c|c|c|}
\hline Author & $\begin{array}{l}\text { Sample } \\
\text { size }(n)\end{array}$ & Age & $\operatorname{Sex}(n)$ & Comorbidities & $\begin{array}{l}\text { Organ } \\
\text { system }\end{array}$ & Gross findings & $\begin{array}{l}\text { COVID-19-related } \\
\text { histological findings }\end{array}$ \\
\hline
\end{tabular}

(PMN) and lymphocytes.

No viral inclusions or giant multinucleated cells were noted. Interstitial compartment showed edema, vascular stasis, lympho-monocytic infiltrates, and abundant megakaryocytes

\begin{tabular}{|c|c|c|c|c|c|c|}
\hline $\begin{array}{l}\text { Edler et al., } \\
\text { Germany [5] }\end{array}$ & 80 & $\begin{array}{c}79.2 \\
(52-- \\
96)\end{array}$ & $\begin{array}{l}\text { M: } 46 \\
\text { F: } 34\end{array}$ & $\begin{array}{l}\text { Overweight, DM, } \\
\text { IHD, COPD, HTN, } \\
\text { and other cardiac } \\
\text { complications }\end{array}$ & Lungs & Large and heavy lungs \\
\hline $\begin{array}{l}\text { Bradley et al., } \\
\text { USA [29] }\end{array}$ & 14 & 73.5 & N/A & $\begin{array}{l}\text { HTN, CKD, OSA, } \\
\text { DM2, and obesity }\end{array}$ & $\begin{array}{l}\text { Lung, } \\
\text { heart, } \\
\text { spleen, } \\
\text { liver, } \\
\text { kidney, } \\
\text { and } \\
\text { brain }\end{array}$ & $\begin{array}{l}\text { Lung: heavy, edematous lung, } \\
\text { intraparenchymal } \\
\text { hemorrhage, pulmonary } \\
\text { consolidation } \\
\text { Spleen: both splenomegaly } \\
\text { and splenic atrophy } \\
\text { Brain: scattered punctate } \\
\text { subarachnoid hemorrhages }\end{array}$ \\
\hline
\end{tabular}

DAD with activated type II pneumocytes, fibroblasts, protein-rich exudate, and hyaline membranes. In advanced stages, squamous metaplasia and fibrosis occurred. In some cases, giant cells and megakaryocytes appeared

ung: DAD, with intra-alveolar fibrin, hyaline membranes, or loosely organizing connective tissue in the alveolar septal walls. Airways and alveolar spaces contained large, reactive epithelial multinucleated cells

Heart: interstitial fibrosis, myocyte hypertrophy, and myocarditis with aggregates of lymphocytes surrounding necrotic myocytes

Liver: congestion, steatosis, periportal lymphocytic inflammation, centrilobular necrosis

Kidney: moderate to severe arterionephrosclerosis, diabetic changes, scattered tubular casts and reactive tubular epithelium, renal vein organizing thrombus

$\begin{array}{llllll}\begin{array}{c}\text { Xu et al., China } \\ \text { [15] }\end{array} & 1 & 50 & \mathrm{M} & \mathrm{N} / \mathrm{A} & \begin{array}{l}\text { Lung, } \\ \text { heart, } \\ \text { and liver }\end{array}\end{array}$

$\begin{array}{ccccccc}\text { Magro et al., } & 5 & 54.4 & \text { M: } 3 & \text { CAD, DM2, ESRD, } \\ \text { USA [13] } & & \text { F: } 2 & \begin{array}{c}\text { Lung and } \\ \text { obesity, OSA }\end{array} & \begin{array}{c}\text { Grossly, the lungs had a } \\ \text { skin } \\ \text { congested and hemorrhagic }\end{array} & \begin{array}{c}\text { Lung: severe organizing } \\ \text { hemorrhagic pneumonitis, } \\ \text { congested interalveolar }\end{array}\end{array}$

Lung: B/L DAD with cellular fibromyxoid exudates. Interstitial mononuclear inflammatory infiltrates, multinucleated syncytial cells with atypical pneumocytes hyperplasia in the intra-alveolar spaces, showing viral cytopathic-like changes

Liver: moderate microvesicular steatosis and mild lobular and portal activity

ung: severe organizing congested interalveolar 
Table 1 (continued)

\begin{tabular}{|c|c|c|c|c|c|c|c|}
\hline Author & $\begin{array}{l}\text { Sample } \\
\text { size }(n)\end{array}$ & Age & $\operatorname{Sex}(n)$ & Comorbidities & $\begin{array}{l}\text { Organ } \\
\text { system }\end{array}$ & Gross findings & $\begin{array}{l}\text { COVID-19-related } \\
\text { histological findings }\end{array}$ \\
\hline
\end{tabular}

septa, with luminal and mural fibrin deposition within septal capillaries

Skin: striking thrombogenic vasculopathy accompanied by extensive necrosis of the epidermis and adnexal structures, including the eccrine coil. There was a significant degree of interstitial and perivascular neutrophilia with prominent leukocytoclasia. It also showed superficial vascular ectasia and an occlusive arterial thrombus within the deeper reticular dermis in the absence of inflammation. Extensive vascular deposits of C5b-9, $\mathrm{C} 3 \mathrm{~d}$, and $\mathrm{C} 4 \mathrm{~d}$ were observed throughout the dermis. There was a modest perivascular lymphocytic infiltrate in the superficial dermis along with deeper seated small thrombi within rare venules of the deep dermis, in the absence of a clear vasculitis. Significant vascular deposits of C5b-9 and $\mathrm{C} 4 \mathrm{~d}$ were observed

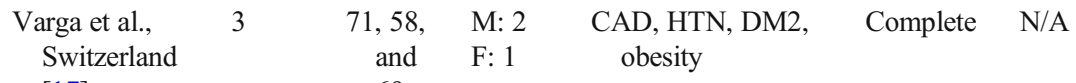

$\begin{array}{cllll}\begin{array}{c}\text { Nicholls et al., } \\ \text { China [53] }\end{array} & 53 & \begin{array}{l}\text { M: } 4 \\ \text { F: } 2\end{array} & \begin{array}{l}\text { HTN, hepatitis B liver } \\ \text { cirrhosis, and portal } \\ \text { hypertension }\end{array}\end{array}$

The lungs were edematous with a grayish brown consolidated cut surface. The consolidation was
Case 1: Transplanted kidney revealed viral inclusion structures in endothelial cells, accumulation of inflammatory cells associated with endothelium, as well as apoptotic bodies, in the heart, small bowel, and lung. An accumulation of mononuclear cells was found in the lung, and most small lung vessels appeared congested

Case 2: lymphocytic endotheliitis in the lung, heart, kidney, and liver as well as liver cell necrosis and small intestine

Case 3: Small intestine resection revealed prominent endotheliitis of the submucosal vessels and apoptotic bodies

Large pneumocytes characterized by nuclear enlargement, prominent nucleolus, and amphophilic 
Table 1 (continued)

COVID-19-related

histological findings

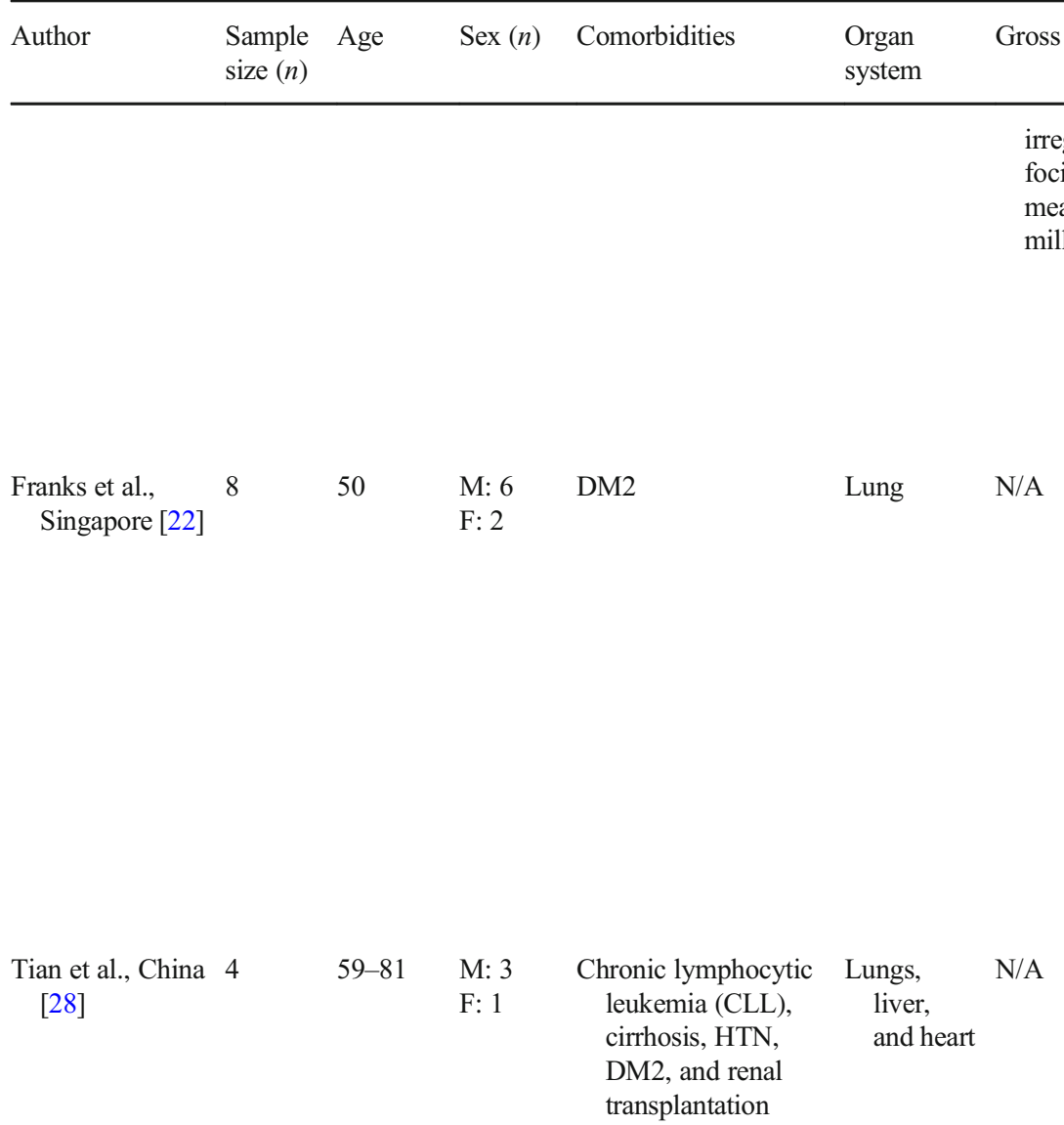

irregular and patchy, with foci of pale tissue measuring up to several millimeters in diameter granular cytoplasm. No typical viral inclusions.

Desquamation of

pneumocytes was a prominent and consistent feature. In addition to the DAD, morphological features of giant cells and pneumocyte hyperplasia were seen in these patients

Cases of shorter duration $(<10$ days) demonstrated histological features of acute-phase DAD, airspace edema, and bronchiolar fibrin. Cases of longer duration (>10 days) demonstrated features of organizing-phase DAD, type II pneumocyte hyperplasia, squamous metaplasia, multinucleated cells, and acute bronchopneumonia

Lung: acute-phase DAD and organizing-phase DAD

Liver: consistent with their pre-existing conditions

Heart: focal mild edema, interstitial fibrosis, and myocardial hypertrophy; no inflammatory cellular infiltration

\begin{tabular}{|c|c|c|c|c|c|c|}
\hline $\begin{array}{l}\text { Suess et al., } \\
\text { Switzerland } \\
{[26]}\end{array}$ & 1 & 59 & M & DM2 and HTN & Complete & $\begin{array}{l}\text { B/L heavy edematous lungs, } \\
\text { pulmonary edema, and a } \\
\text { diffusely firm and rubbery } \\
\text { parenchyma with no } \\
\text { palpable mass. The } \\
\text { parenchyma had areas } \\
\text { ranging from pale pink to } \\
\text { dark red in color with } \\
\text { scattered ill-defined hem- } \\
\text { orrhagic areas }\end{array}$ \\
\hline $\begin{array}{l}\text { Paniz-Mondolfi } \\
\text { et al., USA } \\
\text { [40] }\end{array}$ & 1 & 74 & M & Parkinson's disease & Brain & N/A \\
\hline $\begin{array}{l}\text { Carsana et al., } \\
\text { Italy [10] }\end{array}$ & 38 & $\begin{array}{l}69 \\
(32- \\
86)\end{array}$ & $\begin{array}{l}\text { M: } 33 \\
\text { F: } 5\end{array}$ & $\begin{array}{l}\text { DM2, HTN, } \\
\text { malignancy, } \\
\text { COPD, CVD }\end{array}$ & Lung & $\begin{array}{l}\text { The lungs of all patients were } \\
\text { heavy, congested, and } \\
\text { edematous, with patchy } \\
\text { involvement }\end{array}$ \\
\hline
\end{tabular}

Lung: pulmonary congestion and early-stage DAD

Liver: moderate macro- and microvesicular steatosis as well as some single necrotic hepatocytes around the central veins without portal or lobular inflammation

Heart: patchy nonspecific pericardial infiltration with aggregates of inflammatory cells, including lymphocytes and plasma cells

Transmission electron microscopy revealed the presence of 80- to $110-\mathrm{nm}$ viral particles in frontal lobe brain sections

Exudative and early or intermediate proliferative phases of DAD and fibrotic phase of DAD. Main bronchi and bronchiolar branches revealed focal squamous metaplasia and 
Table 1 (continued)

\begin{tabular}{|c|c|c|c|c|c|c|}
\hline Author & $\begin{array}{l}\text { Sample Age } \\
\text { size }(n)\end{array}$ & $\operatorname{Sex}(n)$ & Comorbidities & $\begin{array}{l}\text { Organ } \\
\text { system }\end{array}$ & Gross findings & $\begin{array}{l}\text { COVID-19-related } \\
\text { histological findings }\end{array}$ \\
\hline
\end{tabular}

mild transmural

lymphocytic and

monocytic infiltrates.

Lumina often contained

residual dense mucoid

material, and granulocytes

were present

$\begin{array}{lccccc}\text { Menter et al., } & 21 & 76 & \text { M: } 17 & \text { HTN, DM2, COPD, } & \text { Lung, } \\ \text { Switzerland } & & (53-- & \text { F: } 4 & \text { CLD, CKD, CVD, } & \text { heart, } \\ {[16]} & 96) & & \begin{array}{l}\text { smoking, obesity, } \\ \text { malignancy, AIDS }\end{array} & \text { and } \\ & & & & \text { kidney }\end{array}$

Bryce et al.,

67

USA [21]
Lung heterogeneous ranging from patchy to diffuse areas of consolidation to severe and extensive suppurative bronchopneumonic infiltrates. In all cases, the lung parenchyma was heavy and firm and unevenly bluish-red in color, with signs of severe congestion

HTN, DM2, COPD, Lung: 25 CLD, CKD, CVD, Heart: 25 smoking, obesity, Spleen: 22 malignancy, AIDS Kidney: 25

Liver: 22

Brain: 23
B/L heavy lungs with an appearance ranging from patchy to diffusely consolidated

All but 1 had gross cardiac enlargement, with many having left ventricular hypertrophy and moderate to marked atherosclerotic narrowing of the coronary arteries
Lung: severe capillary congestion (capillarostasis) accompanied by hyaline membranes, reactive pneumocyte changes, and syncytial cells corresponding to exudative DAD. In 10 cases, superimposed bronchopneumonia with both a focal and a diffuse ( $n$ $=6$ ), microthrombi were detected in alveolar capillaries; 4 cases showed peripheral and prominent central pulmonary embolism

Heart: Peracute focal necrosis of cardiomyocytes as a sequela of shock was seen in 3 patients

Kidney: diffuse acute tubular injury with widened tubular lumina, flattened tubular epithelium, and interstitial edema

Lung: DAD in the acute/exudative or early proliferative phase. Multinucleated cells were observed in cases with pneumocyte atypia, but intranuclear inclusions suggesting viral cytopathic effect were identified in only 2 cases. Electron microscopy presence of multiple spherical virus particles showing spike-like electron-dense peplomeric projections ranging from 100 to $140 \mathrm{~nm}$

Heart: varying degrees of myocyte hypertrophy and interstitial fibrosis, consistent with pre-existing hypertensive and/or atherosclerotic cardiovascular disease

Spleen: well-preserved spleens showed hemophagocytic histiocytes, identified in 9 cases 
Table 1 (continued)

\begin{tabular}{|c|c|c|c|c|c|c|c|}
\hline Author & $\begin{array}{l}\text { Sample } \\
\text { size }(n)\end{array}$ & Age & $\operatorname{Sex}(n)$ & Comorbidities & $\begin{array}{l}\text { Organ } \\
\text { system }\end{array}$ & Gross findings & $\begin{array}{l}\text { COVID-19-related } \\
\text { histological findings }\end{array}$ \\
\hline
\end{tabular}

Kidney:

arterionephrosclerosis,

glomerular mesangial

expansion, mesangial

nodular sclerosis, reflecting

the prevalence of

hypertension and diabetes among this group

Liver: Ischemic coagulative necrosis involving zone 3

was seen in $5 / 22$ cases with 2 showing neutrophilic infiltrates similar to

ischemia-reperfusion injury; 8 cases showed venous outflow obstruction (VOO). Scattered within congested areas are Kupffer cells with phagocytosed red blood cells, indicative of hemophagocytosis

The most striking findings in 20 neuropathological cases reported by Bryce et al. were the widespread and variable presence of microthrombi and acute infarction (6/20). Only 1 case showed a large cerebral artery territory infarct, 3 cases showed small and patchy peripheral and deep parenchymal ischemic infarcts, and others were hemorrhagic. They also noticed out-of-proportion vascular congestion which was occasionally accompanied by acute parenchymal microhemorrhages, especially within the necrotic area of infarction, suggestive of vascular damage and reperfusion injury

Buja et al., USA $3 \quad \begin{gathered}64,32, \\ \text { and } \\ 412]\end{gathered}$
48
Obesity, HTN, heart failure, DM2

Lung,

heart,

kidney,

liver,

and

spleen
Case 1: The lungs were heavy but were free of major thromboemboli and hemorrhages

Case 2: Extremely congested lungs with multiple bilateral segmental pulmonary thromboemboli and multiple areas of hemorrhage; the heart had 4-chamber hypertrophy and dilatation and patent coronary arteries with minimal atherosclerosis
Case 1: early DAD with multiple hyaline membranes accompanied by a focal and mild inflammation with modest numbers of $\mathrm{CD}^{+}$ lymphocytes and more numerous $\mathrm{CD} 68^{+}$ macrophages in some alveolar spaces. The spleen was enlarged. There was expansion of the red pulp not only by congestion but also by a

lymphoplasmacytic 
Table 1 (continued)

\begin{tabular}{|c|c|c|c|c|c|c|c|}
\hline Author & $\begin{array}{l}\text { Sample } \\
\text { size }(n)\end{array}$ & Age & $\operatorname{Sex}(n)$ & Comorbidities & $\begin{array}{l}\text { Organ } \\
\text { system }\end{array}$ & Gross findings & $\begin{array}{l}\text { COVID-19-related } \\
\text { histological findings }\end{array}$ \\
\hline
\end{tabular}

Case 3: Purulent tan opaque watery fluid measuring 500 $\mathrm{mL}$ was found in the right pleural cavity. Yellow translucent deposits were focally present of the visceral pleura along the upper/middle interlobar fissure. Organized tan to greenish exudate with fibrotic thickening was present along the parietal and visceral pleural surfaces of the lower lobe. These were features of empyema infiltrate. The white pulp

was diminished and shrunken with the absence of marginal zones. The kidneys showed evidence of hyaline arteriolosclerosis with glomerulosclerosis.

The liver showed moderate macrovesicular steatosis without evidence of hepatitis

Case 2: Myocardium showed epicardial lymphocytic infiltrates, cardiomyocyte hypertrophy, multifocal interstitial and replacement fibrosis, scattered damaged individual cardiomyocytes, and no inflammatory foci indicative of myocarditis.

The lungs showed evidence of an interstitial lymphocytic pneumonitis with lymphocytic infiltrates around small blood vessels and in the walls of terminal bronchioles extending into alveolar septate.

Microthrombi were found in some pulmonary arterioles. The alveoli contained multiple deposits of fibrin without well-formed hyaline membranes and clusters of pneumocytes

Case 3: The right pleura exhibited empyema. The right lung showed evidence of atelectasis as well as evidence of DAD. The DAD was more pronounced in the expanded left lung. Multifocal lymphocytic infiltrates were present in the epicardium.

Cardiomyocytes showed enlarged hyperchromatic nuclei and changes of acute injury. The liver showed moderate macrovesicular steatosis, lymphoplasmacytic triaditis with portal fibrosis, and early portal-portal bridging fibrosis. The kidneys showed mild hyaline arteriolosclerosis and periglomerular hyaline arteriolosclerosis with rare 
Table 1 (continued)

\begin{tabular}{|c|c|c|c|c|c|c|c|}
\hline Author & $\begin{array}{l}\text { Sample } \\
\text { size }(n)\end{array}$ & Age & $\operatorname{Sex}(n)$ & Comorbidities & $\begin{array}{l}\text { Organ } \\
\text { system }\end{array}$ & Gross findings & $\begin{array}{l}\text { COVID-19-related } \\
\text { histological findings }\end{array}$ \\
\hline
\end{tabular}

holosclerotic glomeruli.

The spleen showed lym-

phocyte depletion in the

white pulp with the absence

of marginal zones; the red

pulp was expanded with

congestion and hemor-

rhage; abundant plasma

cells were present in the red pulp

$\begin{array}{llllll}\text { Copin et al., } & 6 & \text { N/A } & \text { N/A } & \text { N/A } & \text { Lung }\end{array}$

France [11]

Acute fibrinous and organizing pneumonia (AFOP), characterized by extensive intra-alveolar fibrin deposition and intraluminal loose connective tissue within the alveolar ducts and bronchioles associated with the fibrinous acute injury.

Fibroblastic bodies and fibroblasts surrounding intra-alveolar fibrin were seen in all cases, as well as a moderate interstitial T-cell lymphocytic, a plasma cell infiltrate, and type 2 pneumocyte hyperplasia with cytologic atypia.

Vascular injury was also a prominent feature readily demonstrated by endothelial injury with cytoplasmic vacuolization and cell detachment in small- to medium-sized pulmonary arteries

\begin{tabular}{|c|c|c|c|}
\hline Puelles et al., & 0 & 70 & $\begin{array}{l}\text { M: } 16 \\
\text { F. } 6\end{array}$ \\
\hline
\end{tabular}

$3 / 6$ patients had a detectable SARS-CoV-2 viral load in all kidney compartments examined, with preferential targeting of glomerular cells

$\begin{array}{cccc}\text { Wichmann et al., } 12 & 73 \text { years } & \text { M: } 9 & \text { Obesity, CHD, } \\ \text { Germany [23] } & (52-- & \text { F: } 3 & \text { asthma or COPD, } \\ & 87) & & \begin{array}{l}\text { peripheral artery } \\ \text { disease, DM2, and } \\ \end{array} \\ & & & \text { neurodegenerative } \\ & & & \text { diseases }\end{array}$

Complete Majority had heavy lungs, the DAD, consistent with early lung surface often ARDS consisting of displayed mild pleurisy and hyaline membranes, a distinct patchy pattern, with pale areas alternating with slightly protruding and firm, deep reddish blue hypercapillarized areas

\begin{tabular}{|c|c|c|c|c|}
\hline $\begin{array}{l}\text { Solomon et al., } \\
\text { USA [39] }\end{array}$ & 18 & $\begin{array}{l}62 \text { years } \\
\quad(53-- \\
75)\end{array}$ & $\begin{array}{l}\text { M: } 14 \\
\text { F: } 4\end{array}$ & $\begin{array}{l}\text { DM2, HTN, CKD, } \\
\text { CHD, stroke, } \\
\text { dementia }\end{array}$ \\
\hline
\end{tabular}

Gross inspection showed atherosclerosis in 14 brain specimens but no acute stroke, herniation, or olfactory bulb damage activated pneumocytes, microvascular thromboemboli, capillary congestion, and protein-enriched interstitial edema. Thromboemboli were detectable in 4 cases

Acute hypoxic injury in the cerebrum and cerebellum in all the patients, with loss of neurons in the cerebral cortex, hippocampus, and cerebellar Purkinje cell layer, but no thrombi or 
Table 1 (continued)

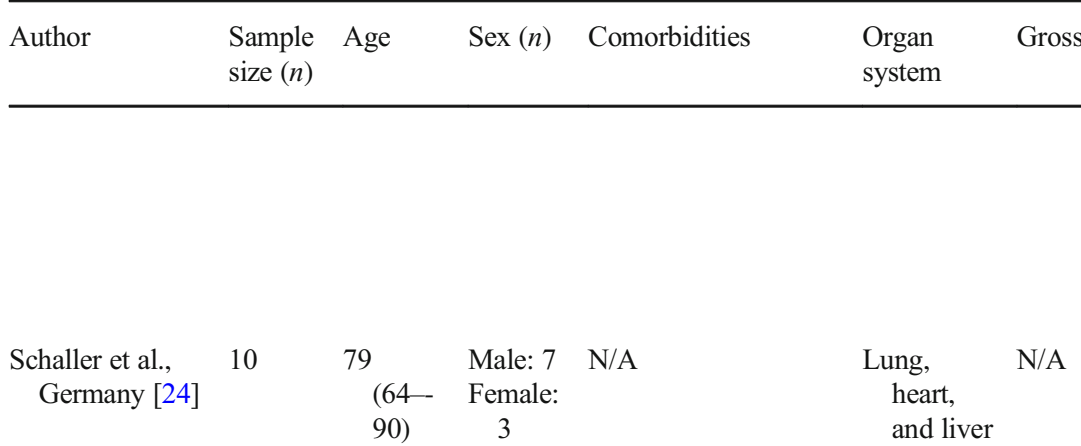

\begin{tabular}{|c|c|c|c|c|c|c|}
\hline $\begin{array}{l}\text { Bruni et al., Italy } \\
\text { [27] }\end{array}$ & 1 & 59 & $\mathrm{M}$ & N/A & Gallbladder & $\begin{array}{l}\text { A relaxed and perforated } \\
\text { ischemic gangrenous } \\
\text { gallbladder, with local } \\
\text { tissue inflammation and } \\
\text { perihepatic fluid }\end{array}$ \\
\hline $\begin{array}{c}\text { Sekulic et al., } \\
\text { USA [32] }\end{array}$ & 2 & 81,54 & M & HTN, DM2, CHD & $\begin{array}{l}\text { Lung, } \\
\text { heart, } \\
\text { liver, } \\
\text { and } \\
\text { spleen }\end{array}$ & $\begin{array}{l}\text { Congested parenchyma } \\
\text { superimposed on } \\
\text { emphysematous changes, } \\
\text { and the left lower lobe } \\
\text { contained a mass lesion }\end{array}$ \\
\hline $\begin{array}{r}\text { Conde et al., } \\
\text { Spain [62] }\end{array}$ & 1 & 69 & M & $\begin{array}{l}\text { Noninvasive } \\
\text { urothelial } \\
\text { carcinoma of the } \\
\text { bladder }\end{array}$ & Lung & $\begin{array}{l}\text { The lungs were heavy and } \\
\text { deep red in color. Pleural } \\
\text { adhesions were present in } \\
\text { the posterior aspects of the } \\
\text { right lung }\end{array}$ \\
\hline
\end{tabular}

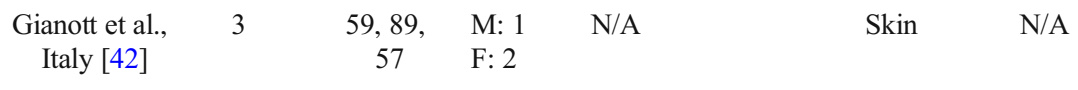


Table 1 (continued)

\begin{tabular}{|c|c|c|c|c|c|c|c|}
\hline Author & $\begin{array}{l}\text { Sample } \\
\text { size }(n)\end{array}$ & Age & $\operatorname{Sex}(n)$ & Comorbidities & $\begin{array}{l}\text { Organ } \\
\text { system }\end{array}$ & Gross findings & $\begin{array}{l}\text { COVID-19-related } \\
\text { histological findings }\end{array}$ \\
\hline
\end{tabular}

pattern. In the mid-dermis, extravasated red blood cells from damaged vessels were visible

Case 3 showed superficial perivascular vesicular dermatitis. Focal acantholytic suprabasal clefts and dyskeratotic and ballooning herpes-like keratinocytes were observed. A patchy band-like infiltration with occasional necrotic keratinocytes and minimal lymphocytic satellitosis were present. In the dermis, the vessels were swollen, with dense lymphocyte infiltration, mixed with rare eosinophils.

Within the epidermis, a nest of Langerhans cells was also observed

\begin{tabular}{|c|c|c|c|c|c|c|}
\hline $\begin{array}{l}\text { Löffler et al., } \\
\text { Germany [44] }\end{array}$ & 3 & $\begin{array}{l}67,85 \\
95\end{array}$ & N/A & $\begin{array}{l}\text { Multiple sclerosis, } \\
\text { HTN, DM2, OSA, } \\
\text { myeloid neoplasia, } \\
\text { Parkinson's } \\
\text { syndrome, } \\
\text { hypertrophic } \\
\text { cardiomyopathy }\end{array}$ & Eyes & N/A \\
\hline $\begin{array}{r}\text { Gupta et al., } \\
\text { USA [36] }\end{array}$ & 2 & $\begin{array}{l}71 \text { and } \\
54\end{array}$ & M & DM2 & Kidney & N/A \\
\hline $\begin{array}{l}\text { Casagrande } \\
\text { et al., } \\
\text { Germany [45] }\end{array}$ & 14 & 77 & $\begin{array}{l}\text { M: } 10 \\
\text { F: } 4\end{array}$ & $\begin{array}{l}\mathrm{DM} 2, \mathrm{HTN}, \mathrm{CAD}, \\
\mathrm{MI}, \mathrm{COPD} \text {, and } \\
\text { malignancy }\end{array}$ & Eyes & N/A \\
\hline $\begin{array}{l}\text { Feng et al., } \\
\text { China [31] }\end{array}$ & 6 & N/A & N/A & N/A & $\begin{array}{l}\text { Spleen and } \\
\text { lymph } \\
\text { node }\end{array}$ & N/A \\
\hline
\end{tabular}

All the eyes showed only patient-specific changes according to the respective previous ocular disease. There was no evidence of SARS-CoV-2-associated inflammatory processes

Both cases had ATI/ATN and a variable degree of podocytopathy (MCD followed by $\mathrm{CG}$ in the first patient and $\mathrm{CG}$ at the outset in the second patient, along with diffuse podocyte foot process effacement PFPE on electron microscopy in both), likely secondary to recent COVID-19 infection

3/14 SARS-CoV-2 viral RNA was detected in the retina of deceased COVID-19 patients

In the spleen, viral NP+ cells were primarily distributed in red pulp and blood vessels, occasionally observed in the white pulp. The lymph follicles and paracortical areas are not identifiable, with necrotic and apoptotic lymphocytes being widely distributed, causing a significant reduction of total lymphocytes, including cells in $\mathrm{T}$ and $\mathrm{B}$ zones. Moreover, interstitial blood 
Table 1 (continued)

\begin{tabular}{|c|c|c|c|c|c|c|c|}
\hline Author & $\begin{array}{l}\text { Sample } \\
\text { size }(n)\end{array}$ & Age & $\operatorname{Sex}(n)$ & Comorbidities & $\begin{array}{l}\text { Organ } \\
\text { system }\end{array}$ & Gross findings & $\begin{array}{l}\text { COVID-19-related } \\
\text { histological findings }\end{array}$ \\
\hline
\end{tabular}

vessels had proliferated and expanded, and were congested. Moreover, the spleens were congested, hemorrhagic, and lacking lymphoid follicles. Additionally, the spleen corpuscles are atrophic, with clear interstitial vessels and fibrous tissue hyperplasia in the splenic sinus

\begin{tabular}{|c|c|c|c|c|c|c|c|}
\hline $\begin{array}{l}\text { Diao et al., China } \\
\text { [35] }\end{array}$ & 6 & 60 & N/A & $\begin{array}{l}\text { HTN, CAD, CKD, } \\
\text { DM, COPD, CeVD }\end{array}$ & Kidney & N/A & $\begin{array}{l}\text { Varying degrees of ATN, } \\
\text { luminal brush border } \\
\text { sloughing, and vacuole } \\
\text { degeneration. Severe } \\
\text { infiltration of lymphocytes } \\
\text { in the tubulointerstitium } \\
\text { (2), moderate infiltration } \\
\text { (3), and absence of } \\
\text { lymphocyte infiltration (1). } \\
\text { Dilated capillary vessels in } \\
\text { the glomeruli. } \\
\text { SARS-CoV-2 NP antigens } \\
\text { were found in kidney } \\
\text { tissues, with NP expression } \\
\text { restricted to kidney tubules, } \\
\text { and NP-positive inclusion } \\
\text { body was also observed }\end{array}$ \\
\hline $\begin{array}{l}\text { Fernandez-Nieto } \\
\text { et al., Spain } \\
\text { [43] }\end{array}$ & 1 & 32 & $\mathrm{~F}$ & N/A & Skin & N/A & $\begin{array}{l}\text { Perivascular infiltrate of } \\
\text { lymphocytes, some } \\
\text { eosinophils and upper } \\
\text { dermal edema }\end{array}$ \\
\hline $\begin{array}{l}\text { Kissling et al., } \\
\text { Switzerland } \\
{[37]}\end{array}$ & 1 & 63 & M & HTN & Kidney & N/A & $\begin{array}{l}\text { Severe collapsing focal } \\
\text { segmental } \\
\text { glomerulosclerosis (FSGS) } \\
\text { and acute tubular necrosis. } \\
\text { Electron microscopy study } \\
\text { showed viral particles, in } \\
\text { the podocyte cytoplasm } \\
\text { and vacuoles that may cor- } \\
\text { respond to viral inclusion } \\
\text { bodies reported with } \\
\text { SARS-CoV-2 }\end{array}$ \\
\hline $\begin{array}{l}\text { Pernazza et al., } \\
\text { Italy [19] }\end{array}$ & 1 & 61 & M & Lung adenocarcinoma & Lung & N/A & $\begin{array}{l}\text { The lung parenchyma } \\
\text { surrounding the neoplasia } \\
\text { showed diffuse } \\
\text { hemorrhages and clusters } \\
\text { of alveolar macrophages, } \\
\text { with occasional } \\
\text { multinucleated cells. } \\
\text { Pneumocyte damage, } \\
\text { alveolar hemorrhage and } \\
\text { clustering of macrophages, } \\
\text { and interstitial } \\
\text { inflammatory infiltrates, } \\
\text { with prominent and diffuse } \\
\text { neutrophilic margination } \\
\text { within septal vessels }\end{array}$ \\
\hline
\end{tabular}


Table 1 (continued)

\begin{tabular}{|c|c|c|c|c|c|c|c|}
\hline Author & $\begin{array}{l}\text { Sample } \\
\text { size }(n)\end{array}$ & Age & $\operatorname{Sex}(n)$ & Comorbidities & $\begin{array}{l}\text { Organ } \\
\text { system }\end{array}$ & Gross findings & $\begin{array}{l}\text { COVID-19-related } \\
\text { histological findings }\end{array}$ \\
\hline $\begin{array}{l}\text { Yao et al., China } \\
\text { [20] }\end{array}$ & 1 & 78 & $\mathrm{~F}$ & N/A & Lung & N/A & $\begin{array}{l}\text { Viral particles in both } \\
\text { bronchiolar epithelial cells } \\
\text { marked by cilia and type II } \\
\text { alveolar epithelial cells } \\
\text { (type II AE) featured with } \\
\text { lamellar body. DAD } \\
\text { includes disruption of } \\
\text { alveolar septa; proliferation } \\
\text { and desquamation of type II } \\
\text { AE; exudation of fibrin, } \\
\text { monocytes, and } \\
\text { macrophages; and } \\
\text { formation of hyaline } \\
\text { membrane. Immune cells in } \\
\text { the alveolar space and septa } \\
\text { were predominantly } \\
\text { CD } 68^{+} \text {macrophages, } \\
\text { CD2 } 0^{+} \text {B cells, and CD } 8^{+} \mathrm{T} \\
\text { cells }\end{array}$ \\
\hline $\begin{array}{l}\text { Zeng et al., } \\
\text { China [18] }\end{array}$ & 1 & 55 & $\mathrm{~F}$ & $\begin{array}{l}\text { Benign pulmonary } \\
\text { nodule }\end{array}$ & Lung & N/A & $\begin{array}{l}\text { Serous exudation, infiltration } \\
\text { of lymphocytes around } \\
\text { blood vessels and in the } \\
\text { alveolar septa, aggregation } \\
\text { of monocytes and } \\
\text { multinucleated giant cells } \\
\text { within alveolar spaces, } \\
\text { hyperplasia of type II } \\
\text { pneumocytes, } \\
\text { intracytoplasmic viral-like } \\
\text { inclusion bodies suggesting } \\
\text { diagnosis of COVID-19 } \\
\text { pneumonia }\end{array}$ \\
\hline
\end{tabular}

Abbreviations: $H T N$, hypertension; $D M$, diabetes mellitus; $C O P D$, chronic obstructive pulmonary disease; $O S A$, obstructive sleep apnea; $C K D$, chronic kidney disease; $C e V D$, cerebrovascular disease; $C A D$, coronary artery disease; $M I$, myocardial infarction; $C L D$, chronic liver disease; $E S R D$, end-stage renal disease; $C H D$, chronic heart disease; $N / A$, not available

on many overlapping pathologies between the viruses seen in an infected host.

In the spleen, splenic pulp atrophy, increase in blood leukocyte count, lymphocyte apoptosis, and splenic infarction were noted [28]. The major pathological changes in the spleen included atrophied white pulp, increase in blood leukocyte count, accumulation of white blood cells around the splenic artery, and increase in neutrophil infiltration [31, 32]. SARS$\mathrm{CoV}$ has been known to cause pathologies in the spleen. The virus has been found to cause the spleen to shrink by about $60 \%$ due to splenic atrophy of white pulp and necrosis [50, 51]. Like SARS-CoV-2, SARS also causes a reduction of lymphocytes including immune cells of all types and can cause macrophage activation. The presence of SARS viral particles has actually been detected in enlarged macrophages [50]. In the liver, there were glycogen accumulation [28], nutmeg congestion, cysts, phagocytic red blood cells [21], nonalcoholic fatty liver disease [16, 28], lymphocytic endotheliosis [17], and centrilobular necrosis [29]. Similar to SARS-CoV-2, many studies have shown that patients with SARS infection had elevated ALT and/or AST during the onset of the infection [55-57]. Additionally, Zhang et al. reported that SARS-CoV infection was found to cause an increase in liver apoptotic cells and a decrease in $\mathrm{CD} 4^{+} / \mathrm{CD}^{+} \mathrm{T}$ cells [58]. MERS had also been shown to cause lobular hepatitis in certain groups of patients [54].

The kidney was affected in two separate regions, namely, the glomeruli where there were severe podocytopathy $[32,36]$ and collapsing glomerulopathy; and the tubules where there was aggregation of erythrocytes leading to tubular occlusion, acute tubular necrosis, acute tubular injury, and fibrin platelet thrombus [33]. In terms of pathological changes associated with MERS, there have been conflicting reports found in the literature. One study reported finding no prominent changes in the kidneys of MERS patients [59], while another study by Cha et al. found a wide array of changes including acute 
tubular necrosis, proteinaceous cast formation, and acute tubular nephritis in a case study on one patient who had contracted the MERS virus [60]. The brain was marked by hypoxic changes in the cerebrum and cerebellum [39], hemorrhaging of white matter, axonal injury, perivascular cell infiltrates, myelin loss, microthrombi, acute infarctions [29], and vascular congestion [21]. While brain impacts of SARS and MERS have not been too widely studied, the SARS-CoV virus has been detected in the hypothalamus and cortex, and autopsies have shown that it causes scattered red degeneration of neurons in these regions [50]. Skin changes were primarily characterized by purpuric rashes, perivascular lymphocytic infiltrates, small thrombi venules, and extensive vascular deposits of C5b-9, C3d, and C4d throughout the dermis [13]. The only major pathological finding in the eyes was conjunctivitis and viral particles were found in the retina of the patients $[44,45]$. Finally, the placenta of SARS-CoV-2-infected mothers had basal plates with adherent myometrial fibers, intervillous thrombi, increased perivillous fibrin deposition, and abnormal formation or injury to maternal villi $[47,48]$.

SARS-CoV-2, SARS, and MERS are all related viruses that show similar pathologic changes. Similar to SARS-CoV-2, both SARS and MERS affect multiple organs. SARS-CoV and MERS have been shown to have overlapping pathologies with SARS-CoV-2 especially in the lungs. SARS-CoV can also lead to DAD, increased lung mass, hyaline damage, increase initial lymphocytes, alveolar macrophages, hemorrhage fibrin thrombi, lung parenchyma, and acute inflammatory exudates, all of which have been found in SARS-CoV-2 patients [49-51, 53]. Moreover, MERS also causes DAD, in addition to necrotizing pneumonia in epithelial cells, pneumocytes, and bronchial submucosal glands [49, 54]. One of the primary differences between MERS, SARS, and SARS-CoV-2 is that the latter is highly contagious and displays many more pathological changes in a wider array of organ systems. Histological and gross changes for SARS have been limited to the lungs, liver, spleen, and brain, while changes as a result of MERS have been limited to the lungs, liver, and kidneys. In the spleen, SARS has been known to cause white pulp atrophy and a reduction of lymphocytes [50,51], while in the liver, it causes an increase in apoptotic cells [58], decreases in $\mathrm{CD} 4^{+}$and $\mathrm{CD} 8^{+} \mathrm{T}$ cells [58], and elevated levels of AST and ALT [55-57]. In the brain, SARS has been linked to scattered red degeneration of neurons in the hypothalamus and cortex [50]. Meanwhile, MERS causes lobular hepatitis in the liver, acute tubular necrosis/nephritis, and proteinaceous cast formation in the kidneys. The wide array of changes as a result of SARS-CoV-2 compared to SARS and MERS could be attributed to having significantly more studies that have reported on SARS-CoV-2 pathologies.

It is interesting that we found multiple studies reporting the presence of viral particles in various organ systems including the lungs, spleen, kidney, brain, and gallbladder. It has been known that multiorgan failure is the second leading cause of death among coronavirus patients [23]. It may be that as the viral disease progresses, the virus begins to target multiple organs outside of the lungs [61]. Since vaccines/drugs to fight against COVID-19 are still under investigation, it becomes crucial to understand the exact pathology of the disease. This may give us more insights into a personalized treatment approach. As a result, literature reviews such as ours are important to help in creating some better understanding of the disease pathogenesis.

\section{Conclusion}

In summary of this literature review, we reported consistent pathological findings associated with some of the organ systems as well as some unique findings in COVID-19 patients. The most common pathological changes were diffuse alveolar damage in the lungs, atrophied white pulp and increase in blood leukocyte count in the spleen, severe podocytopathy and collapsing glomerulopathy in the glomeruli, and acute tubular necrosis, acute tubular injury, and fibrin platelet thrombus in the tubules. The placenta of SARS-CoV-2-infected mothers had basal plates with adherent myometrial fibers, intervillous thrombi, increased perivillous fibrin deposition, and abnormal formation or injury to maternal villi. While vaccines/drugs to combat against COVID-19 are under investigation, it is very important to understand the exact pathology of the disease. Understanding of the COVID-19 pathogenesis will help in setting ground for future research studies into identifying targeted therapies and creating a more personalized treatment approach.

\section{Declarations}

Informed Consent This review article has included already published articles; hence, informed consent was not required. All patient information were de-identified.

Conflict of Interest The authors declare no competing interests.

Copyright Statement The authors have taken copyright permission to reuse the images of the few studies included in the article. The images and their captions have not been modified from their original content. User license agreement is with the corresponding author and will be made available upon request.

\section{References}

1. COVID-19 CORONAVIRUS PANDEMIC. (2020) Worldometer. https://www.worldometers.info/coronavirus/\#countries. Accessed January 272021

2. United States COVID-19 Cases and Deaths by State. (2020) Centers for Disease Control and Prevention (CDC). https://www. cdc.gov/coronavirus/2019-ncov/cases-updates/cases-in-us.html. Accessed January27, 2021 
3. Kaur N, Gupta I, Singh H, Karia R, Ashraf A, Habib A, et al. Epidemiological and clinical characteristics of 6635 COVID-19 patients: a pooled analysis. SN Comprehensive Clinical Medicine. 2020;2:1048-52. https://doi.org/10.1007/s42399-020-00393-y.

4. Patel U, Malik P, Usman MS, Mehta D, Sharma A, Malik FA, Khan N, Siddiqi TJ, Ahmed J, Patel A, Sacks H (2020) Ageadjusted risk factors associated with mortality and mechanical ventilation utilization amongst COVID-19 hospitalizations-a systematic review and meta-analysis. SN Compr Clin Med:1-10. doi:https:// doi.org/10.1007/s42399-020-00476-w, 2, 1740, 1749

5. Edler C, Schröder AS, Aepfelbacher M, Fitzek A, Heinemann A, Heinrich F, et al. Dying with SARS-CoV-2 infection-an autopsy study of the first consecutive 80 cases in Hamburg, Germany. Int J Legal Med. 2020;134(4):1275-84. https://doi.org/10.1007/s00414020-02317-w.

6. Tian S, Hu W, Niu L, Liu H, Xu H, Xiao S-Y. Pulmonary pathology of early-phase 2019 novel coronavirus (COVID-19) pneumonia in two patients with lung cancer. J Thorac Oncol. 2020;15(5): 700-4. https://doi.org/10.1016/j.jtho.2020.02.010.

7. Fox SE, Akmatbekov A, Harbert JL, Li G, Quincy Brown J, Vander Heide RS. Pulmonary and cardiac pathology in African American patients with COVID-19: an autopsy series from New Orleans. Lancet Respir Med. 2020;8(7):681-6. https://doi.org/10. 1016/S2213-2600(20)30243-5.

8. Zhang $\mathrm{H}$, Zhou $\mathrm{P}$, Wei Y, Yue H, Wang Y, Hu M, et al. Histopathologic changes and SARS-CoV-2 immunostaining in the lung of a patient with COVID-19. Ann Intern Med. 2020;172(9):629-32. https://doi.org/10.7326/m20-0533.

9. Aguiar D, Lobrinus JA, Schibler M, Fracasso T, Lardi C. Inside the lungs of COVID-19 disease. Int J Legal Med. 2020;134(4):1271-4. https://doi.org/10.1007/s00414-020-02318-9.

10. Carsana L, Sonzogni A, Nasr A, Rossi RS, Pellegrinelli A, Zerbi P, et al. Pulmonary post-mortem findings in a series of COVID-19 cases from northern Italy: a two-centre descriptive study. Lancet Infect Dis. 2020;20(10):1135-40. https://doi.org/10.1016/S14733099(20)30434-5.

11. Copin MC, Parmentier E, Duburcq T, Poissy J, Mathieu D. Time to consider histologic pattern of lung injury to treat critically ill patients with COVID-19 infection. Intensive Care Med. 2020;46(6): 1124-6. https://doi.org/10.1007/s00134-020-06057-8.

12. Buja LM, Wolf DA, Zhao B, Akkanti B, McDonald M, Lelenwa L, et al. The emerging spectrum of cardiopulmonary pathology of the coronavirus disease 2019 (COVID-19): report of 3 autopsies from Houston, Texas, and review of autopsy findings from other United States cities. Cardiovasc Pathol. 2020;48:107233. https://doi.org/ 10.1016/j.carpath.2020.107233.

13. Magro C, Mulvey JJ, Berlin D, Nuovo G, Salvatore S, Harp J, et al. Complement associated microvascular injury and thrombosis in the pathogenesis of severe COVID-19 infection: a report of five cases. Transl Res. 2020;220:1-13. https://doi.org/10.1016/j.trsl.2020.04. 007.

14. Navarro Conde P, Alemany Monraval P, Medina Medina C, Jiménez Sánchez A, Andrés Teruel JC, Ferrando Marco J, et al. Autopsy findings from the first known death from severe acute respiratory syndrome SARS-CoV-2 in Spain. Rev Esp Patol. 2020;53(3):188-92. https://doi.org/10.1016/j.patol.2020.04.002.

15. Xu Z, Shi L, Wang Y, Zhang J, Huang L, Zhang C, et al. Pathological findings of COVID-19 associated with acute respiratory distress syndrome. Lancet Respir Med. 2020;8(4):420-2. https://doi.org/10.1016/S2213-2600(20)30076-X.

16. Menter T, Haslbauer JD, Nienhold R, Savic S, Hopfer H, Deigendesch N, et al. Postmortem examination of COVID-19 patients reveals diffuse alveolar damage with severe capillary congestion and variegated findings in lungs and other organs suggesting vascular dysfunction. Histopathology. 2020;77(2):198-209. https://doi.org/10.1111/his.14134.
17. Varga Z, Flammer AJ, Steiger P, Haberecker M, Andermatt R, Zinkernagel AS, et al. Endothelial cell infection and endotheliitis in COVID-19. Lancet. 2020;395(10234):1417-8. https://doi.org/ 10.1016/S0140-6736(20)30937-5.

18. Zeng Z, Xu L, Xie XY, Yan HL, Xie BJ, Xu WZ, et al. Pulmonary pathology of early-phase COVID-19 pneumonia in a patient with a benign lung lesion. Histopathology. 2020;77:823-31. https://doi. org/10.1111/his.14138.

19. Pernazza A, Mancini M, Rullo E, Bassi M, De Giacomo T, Rocca $\mathrm{CD}$, et al. Early histologic findings of pulmonary SARS-CoV-2 infection detected in a surgical specimen. Virchows Arch. 2020: 1-6. https://doi.org/10.1007/s00428-020-02829-1.

20. Yao XH, He ZC, Li TY, Zhang HR, Wang Y, Mou H, et al. Pathological evidence for residual SARS-CoV-2 in pulmonary tissues of a ready-for-discharge patient. Cell Res. 2020;30(6):541-3. https://doi.org/10.1038/s41422-020-0318-5.

21. Bryce C, Grimes Z, Pujadas E, Ahuja S, Beasley MB, Albrecht R, et al. Pathophysiology of SARS-CoV-2: targeting of endothelial cells renders a complex disease with thrombotic microangiopathy and aberrant immune response. The Mount Sinai COVID-19 autopsy experience. medRxiv. 2020;2020:2005.2018.20099960. https://doi.org/10.1101/2020.05.18.20099960.

22. Franks TJ, Chong PY, Chui P, Galvin JR, Lourens RM, Reid AH, et al. Lung pathology of severe acute respiratory syndrome (SARS): a study of 8 autopsy cases from Singapore. Hum Pathol. 2003;34(8): 743-8. https://doi.org/10.1016/s0046-8177(03)00367-8.

23. Wichmann D, Sperhake JP, Lütgehetmann M, Steurer S, Edler C, Heinemann A, et al. Autopsy findings and venous thromboembolism in patients with COVID-19: a prospective cohort study. Ann Intern Med. 2020;173(4):268-77. https://doi.org/10.7326/m20-2003.

24. Schaller T, Hirschbühl K, Burkhardt K, Braun G, Trepel M, Märkl B, et al. Postmortem examination of patients with COVID-19. JAMA. 2020;323(24):2518-20. https://doi.org/10.1001/jama.2020.8907.

25. Barton LM, Duval EJ, Stroberg E, Ghosh S, Mukhopadhyay S. COVID-19 autopsies, Oklahoma, USA. Am J Clin Pathol. 2020;153(6):725-33. https://doi.org/10.1093/ajcp/aqaa062.

26. Suess C, Hausmann R. Gross and histopathological pulmonary findings in a COVID-19 associated death during self-isolation. Int J Legal Med. 2020;134(4):1285-90. https://doi.org/10.1007/ s00414-020-02319-8.

27. Bruni A, Garofalo E, Zuccalà V, Currò G, Torti C, Navarra G, et al. Histopathological findings in a COVID-19 patient affected by ischemic gangrenous cholecystitis. World J Emerg Surg. 2020;15(1): 43. https://doi.org/10.1186/s13017-020-00320-5.

28. Tian S, Xiong Y, Liu H, Niu L, Guo J, Liao M, et al. Pathological study of the 2019 novel coronavirus disease (COVID-19) through postmortem core biopsies. Mod Pathol. 2020;33(6):1007-14. https://doi.org/10.1038/s41379-020-0536-x.

29. Bradley BT, Maioli H, Johnston R, Chaudhry I, Fink SL, Xu H, et al. Histopathology and ultrastructural findings of fatal COVID-19 infections in Washington State: a case series. Lancet. 2020;396(10247): 320-32. https://doi.org/10.1016/S0140-6736(20)31305-2.

30. Balaphas A, Gkoufa K, Meyer J, Peloso A, Bornand A, McKee TA, et al. Covid-19 can mimic acute cholecystitis and is associated with the presence of viral RNA in the gallbladder wall. J Hepatol. 2020;73:1566-8. https://doi.org/10.1016/j.jhep.2020.08.020.

31. Chen Y, Feng Z, Diao B, Wang R, Wang G, Wang C, et al. The novel severe acute respiratory syndrome coronavirus 2 (SARSCoV-2) directly decimates human spleens and lymph nodes. medRxiv. 2020;2020:2003.2027.20045427. https://doi.org/10. 1101/2020.03.27.20045427.

32. Sekulic M, Harper H, Nezami BG, Shen DL, Sekulic SP, Koeth AT, et al. Molecular detection of SARS-CoV-2 infection in FFPE samples and histopathologic findings in fatal SARS-CoV-2 cases. Am J Clin Pathol. 2020;154(2):190-200. https://doi.org/10.1093/ ajcp/aqaa091. 
33. Su H, Yang M, Wan C, Yi L-X, Tang F, Zhu H-Y, et al. Renal histopathological analysis of 26 postmortem findings of patients with COVID-19 in China. Kidney Int. 2020;98(1):219-27. https:// doi.org/10.1016/j.kint.2020.04.003.

34. Puelles VG, Lütgehetmann M, Lindenmeyer MT, Sperhake JP, Wong MN, Allweiss L, et al. Multiorgan and renal tropism of SARS-CoV-2. N Engl J Med. 2020;383(6):590-2. https://doi.org/ 10.1056/NEJMc2011400.

35. Diao B, Wang C, Wang R, Feng Z, Tan Y, Wang H, et al. Human kidney is a target for novel severe acute respiratory syndrome coronavirus 2 (SARS-CoV-2) infection. medRxiv. 2020;2020: 2003.2004.20031120. https://doi.org/10.1101/2020.03.04.20031120.

36. Gupta RK, Bhargava R, Shaukat A-A, Albert E, Leggat J. Spectrum of podocytopathies in new-onset nephrotic syndrome following COVID-19 disease: a report of 2 cases. BMC Nephrol. 2020;21(1):326. https://doi.org/10.1186/s12882-020-01970-y.

37. Kissling S, Rotman S, Gerber C, Halfon M, Lamoth F, Comte D, et al. Collapsing glomerulopathy in a COVID-19 patient. Kidney Int. 2020;98(1):228-31. https://doi.org/10.1016/j.kint.2020.04.006.

38. Trigo J, García-Azorín D, Planchuelo-Gómez Á, Martínez-Pías E, Talavera B, Hernández-Pérez I, et al. Factors associated with the presence of headache in hospitalized COVID-19 patients and impact on prognosis: a retrospective cohort study. J Headache Pain. 2020;21(1):94. https://doi.org/10.1186/s10194-020-01165-8.

39. Solomon IH, Normandin E, Bhattacharyya S, Mukerji SS, Keller K, Ali AS, et al. Neuropathological features of COVID-19. N Engl J Med. 2020;383(10):989-92. https://doi.org/10.1056/NEJMc2019373.

40. Paniz-Mondolfi A, Bryce C, Grimes Z, Gordon RE, Reidy J, Lednicky J, et al. Central nervous system involvement by severe acute respiratory syndrome coronavirus-2 (SARS-CoV-2). J Med Virol. 2020;92(7):699-702. https://doi.org/10.1002/jmv.25915.

41. Reichard RR, Kashani KB, Boire NA, Constantopoulos E, Guo Y, Lucchinetti CF. Neuropathology of COVID-19: a spectrum of vascular and acute disseminated encephalomyelitis (ADEM)-like pathology. Acta Neuropathol. 2020;140(1):1-6. https://doi.org/10. 1007/s00401-020-02166-2.

42. Gianotti R, Veraldi S, Recalcati S, Cusini M, Ghislanzoni M, Boggio F, et al. Cutaneous clinico-pathological findings in three COVID-19-positive patients observed in the metropolitan area of Milan, Italy. Acta Derm Venereol. 2020;100(8):adv00124. https:// doi.org/10.2340/00015555-3490.

43. Fernandez-Nieto D, Ortega-Quijano D, Segurado-Miravalles G, Pindado-Ortega C, Prieto-Barrios M, Jimenez-Cauhe J. Comment on: Cutaneous manifestations in COVID-19: a first perspective. Safety concerns of clinical images and skin biopsies. J Eur Acad Dermatol Venereol. 2020;34(6):e252-4. https://doi.org/10.1111/jdv.16470.

44. Löffler KU, Reinhold A, Herwig-Carl MC, Tzankov A, Holz FG, Scholl HPN, et al. Ocular post-mortem findings in patients having died from COVID-19. Der Ophthalmologe : Zeitschrift der Deutschen Ophthalmologischen Gesellschaft. 2020;117(7):64851. https://doi.org/10.1007/s00347-020-01149-8.

45. Casagrande M, Fitzek A, Püschel K, Aleshcheva G, Schultheiss H$\mathrm{P}$, Berneking L, et al. Detection of SARS-CoV-2 in human retinal biopsies of deceased COVID-19 patients. Ocul Immunol Inflamm. 2020;28(5):721-5. https://doi.org/10.1080/09273948.2020. 1770301 .

46. Chen S, Huang B, Luo DJ, Li X, Yang F, Zhao Y, et al. Pregnancy with new coronavirus infection: clinical characteristics and placental pathological analysis of three cases. Zhonghua Bing Li Xue Za Zhi. 2020;49(5):418-23. https://doi.org/10.3760/cma.j.cn11215120200225-00138.

47. Shanes ED, Mithal LB, Otero S, Azad HA, Miller ES, Goldstein JA. Placental pathology in COVID-19. Am J Clin Pathol. 2020;154(1):23-32. https://doi.org/10.1093/ajcp/aqaa089.
48. Baergen RN, Heller DS. Placental pathology in Covid-19 positive mothers: preliminary findings. Pediatr Dev Pathol. 2020;23(3): 177-80. https://doi.org/10.1177/1093526620925569.

49. Bradley BT, Bryan A. Emerging respiratory infections: the infectious disease pathology of SARS, MERS, pandemic influenza, and Legionella. Semin Diagn Pathol. 2019;36(3):152-9. https://doi.org/ 10.1053/j.semdp.2019.04.006.

50. Gu J, Gong E, Zhang B, Zheng J, Gao Z, Zhong Y, et al. Multiple organ infection and the pathogenesis of SARS. J Exp Med. 2005;202(3):415-24. https://doi.org/10.1084/jem.20050828.

51. Hui DSC, Zumla A. Severe acute respiratory syndrome: historical, epidemiologic, and clinical features. Infect Dis Clin N Am. 2019;33(4):869-89. https://doi.org/10.1016/j.idc.2019.07.001.

52. Tse GM, To KF, Chan PK, Lo AW, Ng KC, Wu A, et al. Pulmonary pathological features in coronavirus associated severe acute respiratory syndrome (SARS). J Clin Pathol. 2004;57(3): 260-5. https://doi.org/10.1136/jcp.2003.013276.

53. Nicholls JM, Poon LL, Lee KC, Ng WF, Lai ST, Leung CY, et al. Lung pathology of fatal severe acute respiratory syndrome. Lancet. 2003;361(9371):1773-8. https://doi.org/10.1016/s0140-6736(03) 13413-7.

54. Alsaad KO, Hajeer AH, Al Balwi M, Al Moaiqel M, Al Oudah N, Al Ajlan A, et al. Histopathology of Middle East respiratory syndrome coronavirus (MERS-CoV) infection - clinicopathological and ultrastructural study. Histopathology. 2018;72(3):516-24. https://doi.org/10.1111/his.13379.

55. Xu L, Liu J, Lu M, Yang D, Zheng X. Liver injury during highly pathogenic human coronavirus infections. Liver international : official journal of the International Association for the Study of the Liver. 2020;40(5):998-1004. https://doi.org/10.1111/liv.14435.

56. Zhang C, Shi L, Wang F-S. Liver injury in COVID-19: management and challenges. The Lancet Gastroenterology \& Hepatology. 2020;5(5):428-30. https://doi.org/10.1016/S2468-1253(20)300571.

57. Malik P, Patel U, Mehta D, Patel N, Kelkar R, Akrmah M, et al. Biomarkers and outcomes of COVID-19 hospitalisations: systematic review and meta-analysis. BMJ Evidence-Based Medicine. 2020;26:107-8. https://doi.org/10.1136/bmjebm-2020-111536.

58. Zhang QL, Ding YQ, He L, Wang W, Zhang JH, Wang HJ, et al. Detection of cell apoptosis in the pathological tissues of patients with SARS and its significance. Di Yi Jun Yi Da Xue Xue Bao. 2003;23(8):770-3.

59. Al-Tawfiq JA, Hinedi K, Abbasi S, Babiker M, Sunji A, Eltigani M. Hematologic, hepatic, and renal function changes in hospitalized patients with Middle East respiratory syndrome coronavirus. Int $\mathrm{J}$ Lab Hematol. 2017;39(3):272-8. https://doi.org/10.1111/ijlh. 12620.

60. Cha RH, Yang SH, Moon KC, Joh JS, Lee JY, Shin HS, et al. A case report of a Middle East respiratory syndrome survivor with kidney biopsy results. J Korean Med Sci. 2016;31(4):635-40. https://doi.org/10.3346/jkms.2016.31.4.635.

61. Zaim S, Chong JH, Sankaranarayanan V, Harky A. COVID-19 and multiorgan response. Curr Probl Cardiol. 2020;45(8):100618. https://doi.org/10.1016/j.cpcardiol.2020.100618.

62. Navarro Conde P, Alemany Monraval P, Medina Medina C, Jiménez Sánchez A, Andrés Teruel JC, Ferrando Marco J, et al. Autopsy findings from the first known death from severe acute respiratory syndrome SARS-CoV-2 in Spain. Revista espanola de patologia : publicacion oficial de la Sociedad Espanola de Anatomia Patologica y de la Sociedad Espanola de Citologia. 2020;53(3):188-92. https://doi.org/10.1016/j.patol.2020.04.002.

Publisher's Note Springer Nature remains neutral with regard to jurisdictional claims in published maps and institutional affiliations. 